\title{
Socio-Ecological Implications of Soy in the Brazilian Cerrado
}

Lea Rekow ${ }^{1,2,3}$

${ }^{1}$ Arts, Education \& Law Group, Griffith University, Brisbane, Australia

2 Green My Favela, New York, USA

${ }^{3}$ Bifrost Online, Florida, USA; E-Mail: learekow@gmail.com

Submitted: 15 September 2017 | In revised form: 28 November 2018 | Accepted: 9 December 2018 |

Published: 3 May 2019

\begin{abstract}
This paper summarizes the critical importance of the Cerrado savannah biome in Brazil and examines key ways in which large-scale agriculture, in particular large-scale soy farming, threatens water security and increases socio-ecological stress. It connects agribusiness expansion to the globalized meat industry by defining how complex economic relationships result in deforestation on a massive scale. It describes how this radical change in land cover has led to changes in rainfall patterns that are associated with extended drought periods and analyzes how these critical water shortages jeopardize socio-economic health beyond the immediate region. Further, it explicates how intensified transgenic soy farming and other pesticide-heavy crop production contributes to rising public health crises associated with carcinogen-contaminated water and food sources. Lastly, it identifies emerging trends that suggest how agribusiness corporations and governments may be legally ascribed moral responsibilities for maintaining socio-ecological health of the biome. The paper aims to contribute to a better understanding of the human dimensions of environmental issues and their impacts and reframe conservation social science discourse in regard to protection of land and water resources in the region.
\end{abstract}

Keywords: agribusiness; Brazil; Cerrado; socio-ecological security; soy; water

\section{Introduction}

The Cerrado is one of the most species-rich savannahs in the world [1,2] and a hotspot of biodiversity [3], yet less than $3 \%$ of its area is fully protected $[4,5]$. It is the second largest biome in South America and is the central biome that connects to four of the five other Brazilian biomes-the Amazon, Caatinga, Atlantic Forest and Pantanal. It occupies a continuous region of more than two million $\mathrm{km}^{2}$, covers $23 \%$ of the country, and spans nine states [6]. The headwaters of three of South America's major river basins and several large aquifers are located within its territory. These hydrographic regions play a critical role in the distribution of water resources throughout the South American continent [7].
Large-scale agricultural producers are reshaping the Cerrado on an extraordinary scale [8]. The expansion and intensification of the soy industry is markedly accelerating [4]. From 2000 to 2014 the agricultural area of the Cerrado expanded by $87 \%$, mainly for soybean production, which increased by $108 \%$ during this period [9]. The biome already accommodates 40 million cattle [10] and cultivates more than fifteen million hectares of soy- $90 \%$ of all agriculture in the Cerrado (2013/14 harvest) [9]. Soy production is predicted to continue to increase, in large part to provide agro-industrial feed for the global meat industry [11], particularly to meet demands in China [12,13] and to produce edible oil, biodiesel and industrial products [11,14]. The expansion and intensification of soy, as the main agricultural commodity 
produced in the region, is contributing to changes in regional hydrology [15] that effects water security [16] and impacts the socio-environmental health of the region.

The expanding "ecological hoofprint" [17] of China and Europe's mega-meat industry is a primary driver of soy production on the Cerrado. Yet, understanding how a chain supermarket-bought steak on a European dinner table negatively impacts the ecological health of a Brazilian biome is not straightforward but comprises of a myriad of complex components that are part of a market-based global agri-food industry [18] of which soy is emblematic.

Large-scale production of soy is associated with loss, deterioration and changes in the Cerrado's biophysical foundations. It negatively impacts on native vegetation, soil, groundwater, hydrological patterns, and other elements essential to socio-ecological security [19]. These issues are not only attributable to soy but are interwoven into a transnational landscape that connects to other forms of grain and livestock production and is supported by pro-growth federal and state policies engineered by a powerful agribusiness lobby disproportionally represented in Brazilian Congress [20].

Transnational corporations significantly influence institutionalized decision-making at a national level [21]. The rapid conversion to genetically modified (GM) key commodity crop production (soy, corn, and cotton) in the last two decades has dominated the political ecology of national agriculture, to affect the dynamics of farming, trade, and legislation. The introduction of GM soy in 2008 has accelerated an already expanding industry [22]. In Brazil, 96\% of soy is genetically modified (2016 harvest) [23]. Soy has now become the largest crop cultivated (by area) in the country, with an estimated 33.9 million ha planted in 2016/17 (to produce 114.1 million tons), $74 \%$ of which was to supply the export market, with China as the chief importer, followed by Europe [24].

Soy expansion has destroyed natural habitats over wide areas of both the Amazon and Cerrado, and has been accompanied by massive transportation infrastructure projects that include industrial waterways, railway lines and road networks that transport commodities to port [25]. They further infringe into the biome by providing access for other private neo-extractivist activities [26] to expand.

Along with the expansion of GM soy has come a dramatic increase of agrotoxin use (chemical pesticides/herbicides), the technologies of which belong overwhelmingly to Monsanto (73.05\%) followed by multinationals Dow AgroScience / DuPont and Syngenta (2013) [27]. GM soy has dramatically changed farming on the Cerrado, not only in a material sense, but at an ideological level, as it is progressively transformed into a de-spatialized commodity that is divorced from negative socio-ecological accounting $[11,28]$. As discussed later in this paper, large-scale soy production is justified by calculating dollar value commodity profit over tradable carbon stocks [29], while environmental health impacts caused by pesticide contamination [30] and the effects on changes in regional hydrology patterns [31] are given inadequate policy attention, though they are increasingly significant problems. Thus, in closing, the paper signposts emerging ways forward that suggest how government and agribusiness may be held more legally responsible for their impacts on the Cerrado.

\section{Need}

By 2050 , food production is predicted to increase by approximately $70 \%$ worldwide, and by $100 \%$ in developing countries [32]. The demand for soy, much of it for livestock feed [33,34], and the large-scale mechanized methods used to produce[11] and transport it [35], are supported by a global free market system $[36,37]$ tied to a pro-growth economic development model in critical need of revision [38-44]. Over the coming decades, this model will result in climate changes that are expected to contribute to water scarcity [45] and declines in yields and price increases for key commodity crops such as soy, which will no longer be viable to cultivate in the region [46].

The Cerrado is part of an agricultural frontier that teeters on an ecological 'tipping point' as a result of intense pressure from agribusiness $[47,48]$, much of it in order to expand soybean production [49]. The consequences are enormous and interdependent, and at the same time unique to the biome. Ongoing examination of the environmental stressors the Cerrado faces are of crucial importance in order to understand what is necessary to ensure its socioecological survival. Investigations into hydrological instability, safeguards for human health and wellbeing, and the deepening of discourses that critique the global free market food system and interrogate the culture of agro-extractivism are all essential to decouple discussions of sustainability from an economic model dependent on perpetual growth $[39,44,50,51]$. This refocusing of development discourse must also include strategies whereby government and corporate entities are legally compelled to act in the capacity of socio-environmental stewards over the lands and waters that they use and control.

\section{Aims}

The aim of this paper is to:

a) contribute to existent conservation social science discourse [52,53] analysis by analyzing key ways in which large-scale agriculture on the Cerrado (in particular soy farming) limits socio-environmental security and impacts water resources;

b) frame ecological integrity as a moral obligation which may be legally applied to aid in reversing socioecological loss moving forward.

\section{Scope}

This paper investigates the environmental impact of largescale soy farming in relation to key vulnerabilities by delineating how water security, in particular, is threatened by agribusiness. It defines the role that the Brazilian soy in- 
dustry plays by building a narrative that relates land use to water resource strain, and linking it to a larger suite of land use practices that are transforming the Cerrado and effecting broader security issues. It focuses on soy as a primary and emblematic component of an agribusiness framework that is invested in building political and socio-economic perceptions and attitudes that value the Cerrado exclusively for its commodified worth.

The paper offers considerations for a pathway forward by proposing how emerging legal approaches can be used to intervene in governance to strengthen conservation initiatives beyond the industry-led, market-based instruments currently in place [54].

Many topics are critical to informing the industry responsibility debate. Though each is beyond the scope of this paper to investigate in depth, collectively they form an ethical basis for suggesting an alternative development pathway forward. They include: addressing environmental justice struggles faced by those that are dispossessed by or exposed to violence by a policy landscape that supports neoextractivist industries $[55,56]$ and unethical labor practices [57]; interrogating conservation initiatives which are shaped almost exclusively by an array of market-based instruments such as subsidized credit lines, tax incentives and trade-off schemes, most of which favor large-scale landholders and privatization initiatives [3]; suggesting more rigorous transparency in multi-directional global commodity supply chains [58]; dispelling a neoliberal land transformation imaginary [59]; and indicating emerging ways in which environmental protection responsibilities may be legally ascribed to government and industry in the 21st century.

This paper may be of relevance to practitioners and theorists working in the fields of the conservation social sciences, specifically in areas of environmental sociology, land management, political ecology, development ethics, climate change litigation and environmental geography, with an interest in agribusiness, land use and water resources, but who are unfamiliar or less familiar how sustainability challenges relate to the Cerrado biome.

\section{Methods}

The methodological foundation for this paper is grounded in a critical discourse analysis [60] of existing Cerrado literature that identified common themes of drought, preservation, conservation, sustainability, deforestation, degradation, carbon, contamination, changes in hydrology, pesticides, water security, environmental threats, conservation policy, land conflicts, social inequity, political ecology, socio-ecological loss and climate change impacts. Productivist discourses were identified with themes concerning higher production levels, economic gains, expansion, intensification, transportation, GDP, yields per tonne, corporate name brands (e.g. Monsanto, Amaggi, Cargill), technological production methods, irrigation, agribusiness policy, growth and sustainable development. Analysis of these key themes form what is essentially a review of Brazil's agricultural, social and environmental policies [51] as they relate to the Cerrado.

\section{Literature Review}

Producing soy on the Cerrado depends on resource exploitation that results in substantive socio-ecological loss, effects water resources, and contributes to hydrological change. An array of scholars provide a solid scientific foundation for explicating these environmental concerns. The Union of Concerned Scientists (2016) provides a summary of the critical ecological importance of the Brazilian Cerrado and how soy is a driver for deforestation [2]. Veldman, et al. (2015) [61] argue the need to protect non-forest ecosystems such as the Cerrado. Grecchi, et al. (2013) [62] and Beuchle, et al. (2015) [63] expose how Cerrado land use has changed due to agriculture, and Spera et al. (2016) [64] analyzes how these changes affect water recycling. Rudorff, et al. (2015) [65] geospatially analyze crop dynamics over the last fifteen years to expand understandings of land cover patterns and changes, and Jepson and Brannstrom (2010) [66], and Gusso et al. (2017) [67] explicate economic patterns and influences that lead to high-input agricultural expansion in the biome. Arantes et al. (2016) [68] analyze current carbon and water reserves and indicate what future changes are likely to occur. BatlleBayer et al. (2010) [69] review changes in the carbon sink due to land use conversion in the region, while Brack and Bailey (2013) [70] discuss agricultural commodity supply chains (including soy) by tracing the interrelationships of international trade, consumption, and deforestation.

Other findings, including conservation studies by Carranza et al. (2014) [71] and Espírito-Santo et al. (2016) [72], are foundational to understanding how ecosystem integrity connects to issues of human security. The Critical Ecosystem Partnership Fund's Ecosystem Profile: Cerrado Biodiversity Hotspot (2017) [3] prepared by Sawyer et al., gives a broad, multi-dimensional overview of the biome and the issues, activities and organizations involved in determining its health. Insights presented by authors that compile the articles of the special issue: Soy Production in South America: Globalization and New Agroindustrial Landscapes (2016) [73] published by the Journal of Peasant Studies, and the collected volume Soy, Globalization and Environmental Politics in South America (2018) [74], both edited by Oliveira and Hecht, provide some of the critical underpinnings for this paper. Finally, Wendy Wolford connects environmental justice issues to large-scale agriculture and the social impacts of soy in the region [75].

\section{An Overview of Soy \& its Implications for Water}

With the aid of chemical fertilizers, the Cerrado is able to produce mega-scale commercial yields of corn, sugarcane, cotton, and above all, soy-the crop that is currently enabling the production of massive quantities of meat and dairy globally. Approximately $80 \%$ of the world's soy is processed for animal feed, much of it in Brazil to be sold to export markets [24,76]. Many other global consumer products, from processed foods to cosmetics, also exist thanks 
to a ten-fold growth in the production of Brazilian soy in the last 50 years $[77,78]$ So much of the South American continent has been subjected to agricultural expansion by the GM soy industry that cultivation of the crop has been referred to as a new form of Latin American colonization [79]. The conversion of native Cerrado into fields of soy has enabled Brazil to become the world's largest exporter of soy-and for the first time the largest producer, overtaking the US for the 2018 harvest [80]. Soy accounted for almost $40 \%$ of Brazil's agricultural exports by value in 2014 [81], giving large producers significant influence over economic and political decision-making.

Up to $70 \%$ of the Cerrado's vast tapestry of native plants and trees are connected via a unique and complex root system that has developed over eons and is crucial for ecological, carbon, and water security $[3,82]$. The magnitude and velocity with which the Cerrado's native vegetation is being deforested due to agricultural expansion is a major contributor to Brazil's key emissions sources [3] and a fundamental cause of water stress throughout the region due to the changes it catalyzes in hydrological patterns [64]. The large-scale loss of native vegetation and its replacement by shallow root system crops such as soybeans has resulted in rainwater being less able to infiltrate the ground because the deep root system needed to absorb the water and feed the water table is no longer there. This results in stormwater erosion and affects lake bottom sedimentation processes that inhibit surface water from penetrating to the Cerrado's aquifers [83].

Spera's remote sensing study (2016), which mapped land-use change across the biome between 2003 and 2013, revealed that cropland agriculture increased from 1.2 to 2.5 million ha during this period, and that $74 \%$ was a consequence of expansion into previously intact Cerrado vegetation. According to the study, this has led to decreased water recycling via evapotranspiration over each consecutive year during this timeframe, demonstrating that in 2013, Cerrado croplands recycled $3 \%$ less $\left(14 \mathrm{~km}^{3}\right)$ water than if the land had been covered with native vegetation [64]. Even though evidence suggests that double-cropping can mitigate evapotranspiration losses [64], and some tree cover and wooded lands have been recovered [63], overall acute net losses in native vegetation due to growth in agribusiness enterprises in the region means increased competition for water supplies and escalating water conflicts. Between 2011 and 2016, Brazil saw a 150\% increase in water conflicts, totaling 172 major water conflicts which affected 44,000 families [84].

Deforestation in the biome, notably from soy, has impaired stream-valley systems due to erosion [85] and increased streamflow in small catchment areas [86], a scenario that may eventually lead to a critical reduction in accessible groundwater stores [87]. Further, pesticides have been detected in water catchment areas under intensive agricultural use, with extremely high-peak concentrations exceeding national and European water quality limits in several cases [30]. With the relaxation of riparian requirements on private properties [88], and the increase of land use expansion and intensification expected to continue, particularly in the northeastern and western regions where less annual rainfall and severe droughts are projected, the leaching risk and migration of agrotoxins are expected to increase [30].

The most aggressive deforestation is occurring in the northeast region of Matopiba (an area comprising of the Cerrado portions of the Brazilian states of Maranhão, Tocantins, Piauí and Bahia). Matopiba is one of the poorest regions in Brazil and the last expanse of the biome that is being converted to large-scale mechanized agriculture [89]. The conversion has been catalyzed by a development plan [90], devised by Brazil's Ministry for Agriculture, to advance the large-scale production of soy and other agricultural commodities for export. Even though land prices in the Cerrado have increased rapidly since 2009 , land in Matopiba remains less expensive than other areas of the biome, which makes it attractive for agricultural development. In 2014, $16 \%$ of soy planted in the Cerrado was planted in Matipoba [81]. The expansion of privatized agribusiness interests is also resulting in excessive deforestation and water pollution, which suggests even more strain will be put on water resources in the coming decades [91,92]. Communities are already struggling to sustain local, traditional small-scale farming, with conflicts related to water justice issues proliferating as a result of the private appropriation of water supplies by agribusiness [84].

The majority of Brazil's national emissions are caused by changes in land use, much of it on the Cerrado, especially in Matopiba, where between 2010-2013, large-scale cropland conversion contributed $45 \%$ of total Cerrado forest carbon emissions $[93,94]$. This has implications for hydrology on both a global scale (due to the effects on climate change) and across the biome [4]. On a regional scale, remote sensing shows that during the Cerrado's dry season, evapotranspiration from agricultural land averages $60 \%$ less than what occurs from land covered with native vegetation. As cropland continues to devour native vegetation, the decrease in dry season water recycling may eventually result in delaying the onset of the Cerrado's wet season, which is responsible for the majority of rains the region receives [64].

$72 \%$ of Brazil's total water consumption in 2010 was used for irrigation [95] -yet only a small fraction $(624,000$ ha) [96] of soybean acreage is irrigated, accounting for $12 \%$ of the country's total harvested irrigated crop area for 2006 (last statistics available) [97]. As agriculture intensifies, however, so too does its irrigation needs. In the Cerrado, growing numbers of large-scale, technologicallyequipped farmers with center-pivot and self-propelled irrigation systems are already maximizing the use of the region's numerous perennial rivers and streams [97] in a trend that is predicted to magnify. According to one report, the FAO projects that irrigation in Brazil may increase by up to $65 \%$ by 2024 [98]. Though efficient irrigation technology reduces water usage per hectare, continued industry growth through expansion and intensification amplifies pressure on water resources [99] and exasperates environmental justice in- 
equities $[75,100]$ by impacting water allocation, quality and reserves that may increase vulnerability to climate shocks.

\section{Water: A Cycle of Diminishing Capacity}

The Cerrado supplies water to six of the country's eight largest watersheds, the whole of the Pantanal, eight of the country's twelve river basin districts, and three of the world's largest and oldest aquifers. The Guaraní Aquifer is the second largest aquifer in the world. It lies beneath the sovereign territory of Brazil, Argentina, Paraguay and Uruguay, and has a storage volume of $40,000 \mathrm{~km}^{3}$ —enough to supply an estimated 11 billion people for 100 years with 100 liters of water per person per day [101]. $71 \%$ of the aquifer $\left(840,000 \mathrm{~km}^{2}\right)$ lies underneath $9.8 \%$ of Brazilian territory, yet Brazil accounts for approximately $90 \%$ of all Guaraní water extraction [102]. In contrast, a quarter of Uruguay is located above the aquifer, yet it uses less than $5 \%$ of what Brazil consumes [103]. The South American epicenter of soybean cultivation occurs in the same quadrant of countries that intersect over the Guaraní, with Brazil taking lead as top producer, followed by Argentina, Paraguay and Uruguay, in a region known as the United Soy Republic. Transboundary tensions around the Guaraní Aquifer have seen a regression in cooperation over the last several years [104]. In relation to agriculture, contamination from diffuse sources such as pesticides, and groundwater exploitation that impede the aquifer's recharge rates [104], may reduce its viable use over the long-term.

Over-exploitation of the Guaraní may eventually result in localized and gradual top-to-bottom depletion that may bring subterranean water levels below what can be feasibly accessed [105]. While the aquifer in its entirety may not be in danger of becoming depleted, oversight of consumption is required in order to ensure a continuous, accessible supply, as only a small percentage of rainfall penetrates to replenish it. Over the last several decades, changes in land use above the aquifer as a result of agricultural activity have significantly decreased the amount of rainfall entering the system in some regions. The water required for the production of soy, for example, puts increasing pressure on it as it continues to be over-drafted [92,106]. In 2007 alone, Brazil's soybean exports to just fifteen EU countries contained 11.6 trillion liters $\left(673 \mathrm{~km}^{3}\right)$ of virtual water [107]. If such consumption continues over the coming decades, recharge rates may be reduced to less than half of natural levels in some outcrop areas [103,105,108].

The approximate $50 \%$ of the Cerrado that remains covered with native vegetation [109] is critical to the health of regional hydrology. Deforestation due to agricultural expansion is responsible for a significant decrease in evapotranspiration at a local level, though it does not solely account for all of the recent changes in water balance. Other anthropic activities, including irrigation and reservoir creation, also modify the water balance [7]. Typically, evaporation occurs at a rate of $21 \%$ in savannahs. Changes in land cover type from savannah to pasture and cropland may directly affect the global water balance, as hotspots of evapotranspiration are reduced because of deforestation, consequently shifting the location, intensity and timing of rainfall events, extending dry seasons and altering stream flows [110,111]. Changes in evapotranspiration in the Cerrado also impact on water levels in Amazon rivers, as water from rivers originating in the Cerrado account for a large part of the volume of the Amazon at its mouth [48]. However, absolute consequences of large-scale landscape modification and their impacts on water balances remain unknown [7] and understudied [112]. In addition, the environmental stresses of economic development and water-related public health risks make sustainable water management increasingly complex, particularly as climate change accelerates [113].

\section{The Costs of Doing Business: More Than Just a Dry Spell}

Brazil's climate in the $21^{\text {st }}$ Century can be characterized by multiple, anthopogenically-driven, acute eco-hydorological events, in which the Cerrado plays a critical role. The biome is foundational to much of South America's water resource dynamics because it distributes fresh water to the largest basins, including the Paraná, Tocantins, Paraguai and São Francisco. These watersheds are crucial to the provision of water supply for humans and non-humans, to maintaining eco-hydrologic functioning, and to providing water for industry, agriculture and hydroelectric energy production [7].

Extreme drought events in southeastern Brazil (20142017) [114], in Amazonia (2005, 2010, 2016) [115], and the northeast (2012-2016) [116] are not random climatic anomalies but are attributable to changes in the water cycle due to deforestation [117], transformations and commodifications of waterscapes [118], and failures in land and water resource management and policies [119]. Declining multiyear rainfall patterns continue to worsen socio-economicenvironmental relationships. 2018 saw more than 900 of Brazil's 5,570 municipalities in a state of water emergency due to drought [120]. The dry weather patterns of the meteorological drought dominating the Cerrado over time have become a hydrological drought, resulting in agricultural and socio-economic drought that continues to bring instability throughout Brazil [121].

In 2014, the Paraná Basin that supplies the state of São Paulo with water suffered an extreme drought event[114] which catalyzed a series of dramatic chain-link consequences for the mega-city of São Paulo. The drought, the worst in 80 years, was also linked to climate change caused by deforestation and the drying up of Brazil's aerial or 'flying rivers' that are generated in the Amazon Basin [122]. Impacts were compounded by poor planning and bad management [123], including a loss of up to $30 \%$ of all treated water due to leaks and illegal usage [119]; no recycling program for domestic water; and failures on the part of water resource planning and management sectors to engineer an interconnected reservoir system that efficiently balances inventories to meet demand without the emergency draining 
of dams or tapping of aquifer reserves [119].

Between 2014-2015, these factors collectively resulted in $40-70 \%$ of the 20 million people living in greater metropolitan São Paulo having their water supply halved and access periodically disrupted [124]. Many went without tap water for days at a time, while others opted to leave the city $[125,126]$. Authorities were forced to drill into the Bauru Sandstone division of the Guaraní Aquifer System in order to pump small reserves of water into the Cantareira Reservoir System to supply many of the city's residents with water, possibly compromising the amount of available groundwater over the long-term [127]. Diminished hydropower capacity saw public services (including electricity, the Internet, and São Paulo's metro system) cut for multi-day periods [125]. The increased financial burden carried by electrical distributors forced them to access more expensive sources of power, such as thermal and gas, and caused the government to take out loans from state-run banks to subsidize distributors' higher energy expenses, resulting in brownouts and blackouts and up to a $30 \%$ rise in consumer energy costs [128]. A lack of available drinking water prompted rainwater hoarding in unsecured containers [129], and periodically spiked incidents of vector-borne diseases such as Zika and Dengue [130]. Brazil's declining zero-to-negative growth in 2015 was estimated to be affected by an additional $1-2 \%$; $36 \%$ of all Brazilians faced water supply problems; industry and agriculture were impacted; 40 million people faced water rationing; electricity rationing affected regions which account for $60 \%$ of the country's GDP [124]; and inflation [131] and food prices [132] rose.

Water shortages have also affected the mechanics of the São Francisco River Basin in recent years. The São Francisco is third largest river in the country and the only major river that starts and finishes in Brazil. Nearly $70 \%$ of the water that feeds the São Francisco River originates in the Cerrado. It is one of the most important river basins in South America, covering $7.5 \%$ of Brazilian territory and supplying enough water to irrigate 300,000 ha of agricultural land and service 14 million inhabitants in 504 different municipalities [133]. The São Francisco River's waters are sequestered at the north end of the Sobradinho reservoir system in Bahia (the $12^{\text {th }}$ largest reservoir system in the world). From here, waters are used to enable the surrounding drought-prone region to be agriculturally viable and to feed the São Francisco River Integration and Transposition mega-projects through a $600 \mathrm{~km}+$ series of networked canals that began operating in 2018 to divert $1.4 \%$ of São Francisco River water to temporary rivers in drought-prone arid areas in Northeastern Brazil. The diverted water feeds industry, agriculture and municipality needs in four states (Pernambuco, Paraíba, Ceará and Rio Grande do Norte). The government is in the process of privatizing the project, which has massive operating costs (to be met by the states), and which has been plagued by construction cost overruns, corruption scandals, and protests from environmental and civil society organizations [134].

Before the diversion projects, the São Francisco River was already losing water at a rate of $3.3 \mathrm{~km}^{3}$ per annum (2002-2015) [130]. Levels have been critically depleted for several consecutive years, and in 2014 the river's headwaters dried up completely for the first time in history [135]. In 2016, the Sobradino reservoir operated at only $18 \%$ of capacity, a level almost too low to access. In 2017, the Brazilian water regulator-Agência Nacional de Águas (ANA) - was forced to limit companies' water abstractions from the São Francisco for several months to combat low levels due to decreased rainfall [136] and as a consequence of illegal syphoning for irrigation (an estimated 20 million $\mathrm{m}^{3}$ of water was syphoned in a 2.5 month period) [137].

Cumulative agricultural impacts, changing hydrology patterns, and climate changes that originate on the Cerrado contribute to impact many of Brazil's hydrographic regions. The Tocantins-Araguaia is another at risk. It covers 967 thousand $\mathrm{km}^{2}$ and contains parts of the Amazon and Cerrado biomes within its boundaries. This region, much of it located in an area known as the 'arc of deforestation,' is under intense strain from land-use changes relating to the highly-mechanized farming of soybeans, sugarcane, and other grains [138]. As agribusiness expands and intensifies, especially with the relaxation of foreign ownership restrictions [139] and the country on the cusp of its largest transgenic soy boom yet [140], ongoing water transport infrastructure investments [141], water conflicts [100], energy insecurity [142], and environmental health concerns all continue to amplify.

\section{The Overuse of Agrotoxins}

The cultivation of GM soy has resulted in the growing consumption of a generation of agrotoxins that are increasingly responsible for numerous environmental health problems [30,143-146]. In 2003, with the introduction of GM crops into Brazil, the country's use of agrotoxins increased by more than $200 \%$ [145]. This figure continues to rise at an annual rate of approximately $15 \%$, more than double the global rate [147]. Since 2008, Brazil has become one of the largest users of agrotoxins in the world, consuming $20 \%$ of the global supply [145], with the majority being used on transgenic soy [148]. Though the use of pesticide on soy is intensifying, soy shows extremely low gains in productivity from its use, displaying a 1:13 percentage point (pp) ratio. In comparison, two other GM crops that account for Brazil's major pesticide consumption - corn and cotton-show an approximate $1: 1 \mathrm{pp}$ productivity ratio [149]. This demonstrates that soy production is not effectively enhanced from increased pesticide use but rather it contributes to the cumulative growth of nation-wide agrotoxin consumption, which is increasing at a rate higher than overall crop productivity [149].

In 2013, Brazilians purchased in excess of $\$ 10$ billion worth of agrotoxins [147] prepared almost entirely by just six companies-Bayer, Syngenta, BASF, Monsanto, Dow, and Dupont-the same transnational corporations that control all the GM crops grown globally for commercial purposes [145]. Poor regulatory oversight [150] around the indus- 
try has made Brazil an attractive market for more than 400 types of pesticides that are banned in other countries [147,148]. In 2015, Brazil planted 21 predominant crops over 71.2 million hectares. Soy accounted for $42 \%$ of the country's total planted area (32.2 million hectares) and used the most pesticides, accounting for $63 \%$ of the total, around 207 million liters [151]. The most used active ingredient is glyphosate, that accounts for approximately $5.2-+5.5$ liters per hectare [152].

By 2015, it was estimated that each and every Brazilian was ingesting 7.3 liters of agrotoxins per year [153]. The primary pesticide pathways to surface and groundwater occur through wind drift as a result of aerial spraying, runoff from agricultural fields in areas where riparian vegetation has been depleted, and leaching through soil macropores [30]. Though drinking water monitoring data is far from comprehensive [154], some grain-producing areas in the Cerrado [155] have detected pesticides in the Guaraní aquifer and wells-in concentrations that exceed Brazil's minimal water quality limits [156]. The absence of controls on well designs and closures may cause some wells to operate as open channels for surface contamination. It is presumed that further contamination is occurring, especially in vulnerable outcrop areas [156,157].

The extensive areas of high pesticide consumption are mainly located in the Cerrado [151]. Reports in connection to acute and chronic pesticide poisoning have escalated over the years $[146,148,158]$. In 2006, the Lucas do Rio Verde municipality in Mato Grosso (population 55,000) experienced toxic rains as a result of plantation crop fumigation with Paraquat, a herbicide used in the drying of soy for harvest [145]. Subsequent health studies conducted between 2007 and 2010 in the same municipality discovered contamination in $83 \%$ of drinking water supplies in drinking water wells, and in two lagoons, as well as in the blood of toads (congenital malformations in these toads were found to be four times more prevalent than those observed in a control lagoon). Glyphosate, pyrethroids, and organochlorines were found in the urine and blood of $88 \%$ of teachers sampled in the region's municipal schools, and in $100 \%$ of samples of women's breast milk [145].

Nationwide health indicators show a positive correlation between the consumption of pesticides, fetal malformation, and chronic childhood cancer in areas predominantly planted with soybeans, corn and sugarcane crops [151], with the intensity of agricultural production and pesticide use proportional to sites of environmental pollution [159]. 4,003 cases of agricultural pesticide poisoning, or almost 11 a day, were reported nationwide in 2017, including 148 deaths [160]. The level of glyphosate present in GM soy has been found to be 19,500 times higher than the level found to have estrogenic effects on breast cancer cells in vitro [161], a level even Monsanto admits is "extreme" [162]. These issues are part of a landscape of environmental violence that is structured by a meagerly enforced legal regulatory framework that continues to be both shaped and threatened by Brazil's powerful agricultural lobby [147].
One of many recent attempts to relax agrotoxin regulations came in June 2018, through a special committee that approved a report recommending the adoption of what has come to be known as the Poison Bill [163]. The agrotoxin regulatory process is currently overseen by the Ministries of Agriculture, Health and the Environment, however if the bill is passed into law, it will transfer oversight directly to the Ministry of Agriculture. It will also lift bans on agrotoxins that are currently prohibited and reduce the testing period for newly introduced pesticides to two years (from five), whereupon registration could be automatically authorized. The bill also proposes that products containing teratogenic, carcinogenic or mutagenic properties should be analyzed only if they are considered dangerous to human health, but Brazilian institutions lack the resources to conduct such analyses [164].

Even though the external costs of pesticide usage - to the environment and to human health-are being brought into questions [18], long-standing institutions such as Brazil's National Council for Food and Nutrition Security are being abolished (the Council was eliminated on the first day Jair Bolsonaro took presidential office) [165]. In January 2019, 40 new products containing pesticides, including 28 new registrations of pesticides as their primary ingredient were approved for sale (12 were approved within a week of Bolsonaro taking office).

Decades ago, Rachel Carson identified the victims of pesticide poisoning as those who "assume the risks that the insect controllers calculate" [166]. This is certainly true in Brazil, in a scenario that may be most tersely characterized as a measure of what Michael Watts describes as the "violent geographies of fast capitalism" [167]. Still, pesticide use and impact remain only part of any sustainability or environmental justice equation. Eco-responsibility means different things to different experts and different stakeholders. Pesticide levels, productivity per acre, water usage and quality, and an array of other scientifically measurable and qualitative factors are part of complex, value-based ideologies that build narratives to constitute or defend dialectic perspectives on what sustainable agriculture means and how it can be achieved.

\section{Agribusiness \& the Politics of Selective Policies}

Brazilian institutions mediate economic and social change and structure key land use change on the Cerrado by determining how and where natural resources are exploited and who benefits from them, in what Jepson and Brannstrom (2010) have described as "access regimes" [66]. The environmental costs of agribusiness, in terms of deforestation, have been justified by calculating that the dollar profit derived both directly and indirectly from the agriculture sector surpasses the dollar trade value of $\mathrm{CO}_{2}$-e emitted through land clearings [29]. The ecological worth of the Cerrado is commodified and assessed by a development perspective that values the growth of primary goods production for export over maintaining the integrity of the carbon sink and 
the natural resources that provide for maintaining global human security in a rapidly warming planet. The agricultural \$profit $>$ carbon sink value is not a logical trade-off platform on which to secure either ecological stability for the biome or build a sustainable agricultural future, but a feature of accumulation by agricultural dispossession [168].

Mega-farming poses huge challenges for agricultural, ecosystem and hydrological sustainability, with climate change due to deforestation on the Cerrado agricultural frontier emerging as a prime factor [169]. The conversion of forests to pastures and cropland has decreased annual mean evapotranspiration in the biome by approximately one third [64,68,169-171] and increased sensible heat fluxes and surface temperatures by $3-5^{\circ} \mathrm{C}[169,171,172]$. By 2050 , climate change is expected to cause water scarcity, dramatic drops in key crop yields and steep increases in their prices [173-175].

Large-scale mechanized soy production has been shown to reduce poverty indicators, raise median rural incomes and lead to increases in the Gini coefficient and the Human Development Index in soy-producing municipalities [176]. However, it also leads to more inequality $[176,177]$, is immunized by technological processes, and incentivized by low-cost chemical registration, subsidies, and low taxes for agrotoxin manufacturers. These, and other agribusiness incentives, engineered by the Brazil's agricultural lobby and explosive industry growth, exploit fragilities in environmental legislation in favor of chemical-dependent farming $[147,151,160,163]$. Large-scale agriculture receives the lion's share of total public agricultural expenditure, dispensed in the form of credit lines, insurance, minimum price guarantees/deficiency payments and technological innovation transfers $[178,179]$. However, of the $9.5 \%$ of farms that accounted for $86 \%$ of total production value in 2006 (last statistics available), the majority were small- and mediumsized [8]. Still, their contributions are marginalized by mainstream political processes[180-183] and thus, four million small farm units have been eliminated from the market [184] by excluding them from access to technology, credit, and insurance. Conversely, disproportionate support for largescale farms has allowed them access to the international market at a higher price and provided them with the tools to negotiate lower costs inputs with suppliers [184].

Consolidation of land and water resources is central to Brazil's neo-extractive economy of state-led agricultural development and is an intrinsic result of an ongoing historical process that supports a highly concentrated system of land ownership [92,185,186]. Brazil has one of the most unequal land structures in the world, with just $1.5 \%$ of rural land owners effectively occupying more than half of Brazil's agricultural lands [187]. Large-scale landholders that control the majority of land use on the Cerrado and other rural areas of Brazil are politically organized through a powerful agricultural lobby - bancada ruralista (rural bench) - a caucus of politicians representing rural interests [20].

The rural bench consists of 228 lawmakers, which make up $44 \%$ of Brazil's lower house of congress and more than
$25 \%$ of the senate. The leader of the bancada ruralistas is Blairo Maggi-head of the Amaggi Group (Brazil's largest soy producing family) and currently federal former minister [188]. The bancada caucus is a key influencer of federal policies that shape environmental protections and promote agribusiness agendas. In a society that is $86 \%$ urban, bancada ruralistas wield extraordinary power over the political system by promoting policies that keep agribusiness as the steadfast of the country's economic epicenter. Brazil's recent President, Michel Temer, survived two congressional votes on whether he should face trial for corruption, in large part due to the backing of the ruralistas [189,190].

Temer's administration passed or attempted to pass a series of laws that benefit agribusiness and accelerate deforestation. Among them is provisional measure 759/2016 [191], dubbed the 'land-grabber's law', a series of land regularizations that ease acquisition of legal title by legitimizing and fast-tracking the transference of public assets (land) and natural resources to private interests (at low or zero cost) without any social or collective interest criteria [192]. The government also proposed to reduce or eliminate environmental licensing and proposal requirements for infrastructure projects [193-195], worked to reduce the size of conservation reserves [196] and deforestation monitoring [197], weakened Indigenous rights [198] by essentially dismantling the bureau of Indian affairs [199], and opened Indigenous territories to mining and agribusiness [200-202].

The 2018 election of Temer's far right successor, Jair Bolsonaro, signals even more disturbing policies that threaten socio-ecological protections for both the Amazon and the Cerrado. Bolsonaro has declared that the Ministry for Agriculture and the Ministry for the Environment will merge and that the Ministry for the Environment will be subjugated to the authority of the Ministry for Agriculture. Bolsonaro also campaigned to dismantle NGOs [203], to jail or exile adversaries and those on the political left[204], and to quash activism [205]—with explicit qualification that "Shiite environmental activism" and the "Indian land demarcation industry" will not be tolerated [206]. He has further stated he will abolish the demarcation of Indigenous and quilombola lands [207], and considers land occupations terrorist acts that may be legitimately suppressed by extrajudicial, lethal means [208].

\subsection{Foreign Ownership and Transnational Issues}

With the introduction of Bolsonaro's policies, agribusiness is set to be fast-tracked with even fewer environmental constraints. Soybeans have historically played a central role in advancing transnational agribusiness in Brazil. Stateled colonization projects such as Prodecer [94,209,210]; a world food crisis and the 2008 financial crisis that was connected to it [211] which consolidated food security with financial returns [212]; and the market liberalization and privatization gains made during the commodity boom 20072014 , brought a swell of private/foreign capital to develop global supply chains [213]. 
Global trade liberalization under the WTO has stimulated trade links between Brazil and China and Brazil and Europe. China's liberalization of soybean imports has made it the world's largest importer of soybeans-with more than half coming from Brazil. The extraordinary growth in the industry has been magnified by the large-scale replacement of alternative forms of edible vegetable oils and meal for animal feed with soy products [214,215]. With record yields and profits and the trade war between the US and China, Brazil is on track to become an even larger soy exporter $[216,217]$. Much of the challenge is being met by expanding river transportation infrastructure [218,219], enabled by the support of various public and private Dutch interests [220], to make it viable to get soybeans to port through a northern corridor. Low-interest, often-subsidized credit lines, available through national development banks and subsidized availability of productive technologies, have also made soy extremely profitable and fueled both its expansion and intensification.

Moving forward, development will remain dependent on financialization, subsidization, access to cheap land, lax restrictions on foreign ownership, construction of new infrastructure (highways, river channels and ports), technological advancements (fertilizers, pesticides, and agrimechanization processes), deforestation, intensification and water diversion. The socio-environmental costs are huge. The northern corridor is expected to create massive socio-ecological disruptions by increasing deforestation, logging, environmental pollution, foreign land occupation and violence between local and Indigenous populations and large landowners [220]. Similarly, soy expansion in Matopiba has resulted in mass dispossession, where the appropriation of public lands for soy cultivation have been legitimized through sophisticated forms of territorial transfer and control [94]. Here soy cultivation increased by $253 \%$ from 2000 to 2014, to cover 3.4 million hectares [9]. According to a 2018 policy briefing analysis [221,222], between 2009 and $2013,70 \%$ of direct soy deforestation in the Cerrado took place in just fifteen municipalities of the Matopiba region [223]. Between $57 \%$ and $90 \%$ of this soy is produced for the export market and has direct and indirect impacts on ecosystem services, especially water provision [221].

Brazil's 2013 irrigation law [224] is key in incentivizing public and private irrigation projects that facilitate intensification and expansion. The law follows a 2009 recommendation by the World Bank that claims production growth will be achieved by:

"...providing investors with greater flexibility, since, to a greater or lesser extent, they would allow for (i) the consolidation of the irrigation service through agricultural occupation within one large company or a vertical consortium of companies; or (ii) free negotiation, under a market scheme, between the irrigation service provider and agricultural producers. This freedom could be perceived by investors as an indicator of lower risk, since these investors would have control over the selection of their partners, consortium members, and contracted parties, free from new bidding procedures. Guarantees for payments, tariffs (or prices), and implemen- tation or occupation terms would be freely negotiated by the parties, within their sphere of private negotiation" [225].

Cerrado regions with a high concentration of irrigated areas are dangerously reducing water supplies and generating conflicts for those that live in basin areas constantly under threat from water overuse [226,227]. Estimated to be 3.5 times more productive than rain-fed agriculture, irrigation allows estimated economic gains up to seven- or eight-fold greater [228]. However, the growth of intensification facilitated by irrigation also brings water insecurity with it. Though current soy output in Mato Grosso (which has been aggressively deforested and now produces primarily through intensification) still relies almost exclusively on rain-fed systems, irrigated systems will nonetheless play an important role moving forward. With irrigation, soybeans can be planted one month earlier and irrigated until the start of the wet season, allowing for an earlier harvest and, potentially, a fully irrigated dry season crop. Increasing irrigation not only increases annual water vapor transfer to the atmosphere through evapotranspiration at the expense of surface and groundwater, it also requires expanding infrastructure to facilitate it [229].

Intensified production of GM soy, which made up $96 \%$ of soy cultivated in Brazil in 2016 [230], together with an irrigated dry season crop and heavy agrotoxin use [231], reinforces a pro-growth perception that is tied to a market logic which rationalizes negative socio-environmental impacts and trade-offs [232-234] and raises conservation costs [232].

Approximately $30 \%$ of all lands available for crop expansion are located in Latin America and by 2050 approximately $80 \%$ of intensified production worldwide is expected to rely on irrigated agriculture [235]. Thus, South America's water supply paradox is apt to become more pronounced with calculations suggesting that $60 \%$ of all accessible blue water (freshwater) would have to be appropriated for agriculture [235] to meet the projected demands of intensification globally-an unsustainable proposition that will increase pressure on terrestrial and aquatic ecosystems, and traditional cultures and livelihood systems that struggle to survive on already-stressed common property (land, water, forests and fishing).

Much socio-ecological security in Brazil, however, is ultimately determined by the green water stored in the soils of the Cerrado. Its abundance or scarcity and the linkages between green and blue water flows are inextricably tied to a healthy ecology and water cycle. As regional hydrology patterns are altered, and climate change accelerates, gradual changes in political ecologies will be forced to reconcile the differences between institutional and corporate interests and the interdependencies between economic and environmental realities. The already high social costs will be higher and will amplify already long-standing conflicts with established agribusiness practices.

\section{A Difficult Path Forward}

There is an accepted philosophical position in contemporary society whereby if an institutional agent has the capacity, 
power, and resources to aid in solving a problem, they have a responsibility to do so $[236,237]$. However, ethical imperatives are based on moral and political complexities that require applying a series of judgements, legal or otherwise, that in practical usage are often in dialectic opposition to one another-played out in various assemblages of contradictory regulatory and trade frameworks at sub-national, national and international levels [238].

Environmental ethics posit that the intrinsic value of natural resources and environmental costs must be included in the evaluation of capital investments in development and sector policy, yet these evaluations almost exclusively occur through cost-benefit analyses in which minimizing economic cost typically remains the central, controlling, and diluting measure for environmental threat assessment [239]. The ethical responsibilities relating to climate change may be more difficult to ignore in coming decades because of the interrelated societal consequentialism that is compounding impacts on multiple simultaneous levels. These impacts are already reconceptualizing how responsibilities can be assigned to address accelerating environmental problems.

Agribusiness on the Cerrado comes at the expense of biotic, aquatic, traditional, and Indigenous life, all of which have been relegated to surviving in conservation fragments interspersed between private lands and ultimately threatened by extinction. Such a dilemma was theorized decades ago by Aldo Leopold in his seminal essay The Land Ethic (1949). Leopold contended that government conservation efforts would eventually be crippled by an unbalanced system based solely on economic self-interest, which would ignore (to the point of elimination) land community elements that lack commercial value but that are intrinsic to healthy function. He further queried that if ethical obligations are not materially assigned to the private landowner, who would carry the "eventual ramifications"? [240] Climate change is emerging as a peripheral argument that may be central to dispensing such responsibility.

By 2017, there were more than 1,200 climate change or climate change-relevant laws in place worldwide [241]. Existing national and international laws cover a large portion of the globe, however, there remains a need to strengthen and enforce legislation and fill gaps in existent laws. Even with climate change as a peripheral issue (in $77 \%$ of suits, climate change is a partial or motivating argument) [241], the judiciary is increasingly confronted by disputes involving climate change-related issues. Such cases aimed at establishing regulatory protections are becoming more frequent.

Climate change is yet to be used as a central strategy to litigate against agribusiness-related GHG contributions, however, as a peripheral argument they are emerging. A 2018 lawsuit was lodged by an environmental advocacy group against the German government for its complicity in failing to curb nitrates from seeping into groundwater, mostly as the result of factory farming operations [242-244]. The strategy aims to force an emissions cap on methane production, and thus reduce overall farm sizes. These sorts of actions could, theoretically, become instrumental in alter- ing the course of livestock feed production, transportation and imports. Thus, the links connecting industrial farming become vulnerable as they are exposed to climate change litigation, if only as a peripheral argument [245,246].

Most successful climate change litigation decisions tend to favor pro-regulatory positions involving energy efficiency or renewable energy technologies [247-249]. Using renewable energy to replace fuels made from cash crops such as soy are already taking the form of pro-regulatory recommendations that are more frequently finding their way into agriculture and energy policy recommendations and blueprints globally [250-254]. These shifts in the energy landscape may eventually have ramifications for international commodity trading. Incorporating climate change mitigation measures into crop insurance and conservation compliance programs, and building emissions reduction and carbon sequestration caps into agriculture bills may also be a method for government to assign corporate responsibility.

Other internationally spearheaded conservation efforts [255] are underway to create legal recognition of the rights of nature [256] and governmental duties of care. Constitutional amendments and bills that champion these concepts have been adopted in Mexico City [257] and are tabled in Argentina [258] and Europe [259]. New Zealand has imbued a number of its rivers and forests with personhood rights, India has declared personhood rights for the Ganges River, and a 2018 ruling by the Columbian Supreme Court imbued sovereign Amazon forest with personhood right and declared that the federal government has a resulting duty to protect it. Going further, Bolivia and Ecuador have passed legislation granting all nature equal rights to humans [260]. Among these jurisdictions that have developed concepts of environmental personhood, applications and understandings of it are diverse.

As the concept becomes more widely applied, environmental personhood may be the next line of attack for redressing environmental protection policies that arguably fail in their care of duty. The concept could prove useful for another challenge [261] to Brazil's revised 2012 Forest Code-a set of controversial laws that regulate land use and management on private properties. It is of particular importance because $76 \%$ of rural landholdings in Brazil exist on private land and $80 \%$ of regions converted to soybean plantations have occurred in areas that are permitted by the FC [262], much of it by removing native vegetation from Cerrado lands [9]. FC revisions also grant select amnesty for illegal deforestation, reduce standards for conservation and restoration by up to $78 \%$ in some areas $[9,263]$, and reduce Areas of Permanent Protection-some of which are located in headwaters, lakes and rivers in areas of strategic importance for agribusiness - which are crucial for maintaining water supplies and preventing climate disasters.

The common law public trust doctrine (PTD), central to environmental law, is also being advanced as a ground for compelling regulation of GHG emissions [264,265] through judicial means [266]. Brazil has no judicial interpretation of the public trust doctrine but has constitutional provisions 
(including articles $5,20,23,24,225)$ that embrace its principles [267], which could be legally applied to protect the Cerrado irrespective of its commercial value.

Under international law, the Precautionary Principle [268-270] may be used to stop the use of technological enhancements for short-term economic gains at the expense of future generations if environmental damage by one nation state causes serious and irreversible consequences to another. The principle is often cited in official documents pertaining to international environmental commitments and may be useful to consider in regard to issues pertaining to Brazil's disproportionate over-drafting of the Guaraní Aquifer, or applied to slow land use conversion that can be definitively linked to hydrology changes in neighboring nation states, as crop production is directly achieved through the aid of technological enhancements such as GM production methods enabled by technical investment and financing sectors. This argument may also, theoretically, be invoked to block the uptake of the 'Cerrado Miracle' in cases such as Mozambique's controversial ProSavana initiative [271-273].

Over the last decade, chemical pesticide manufacturing industries have increasingly become a target of litigation. Law suits are more frequently finding ways into the court to hold agribusiness accountable for the environmental consequences of their operations, especially in regards to the ethical concerns about the culture of pesticides associated with GM crop production, including their links to climate change vulnerability [274,275], public health, ecological damage, negative impacts on traditional farming practices, and excessive corporate dominance [276]. In Brazil, laws are being introduced to regulate how pesticides are transported and handled [277,278], and a 2018 federal ruling has temporarily suspended the registration of new pesticides until a toxicity evaluation is completed [279]. This is despite the rural bench's attempts to pass the poison law and ban the sale of organic produce in supermarkets domestically, which would disproportionately affect small-scale farmers [280].

The Landless Workers Movement (MST) is the largest and most mobilized social justice and agrarian reform movement representing small-scale stakeholders effected by multiple agricultural stressors [92,93,281-288]. MST is mostly composed of farmers, working people, Indigenous peoples, those living on quilombos and local communities who rely on small-scale and subsistence farming and fishing [289].

The MST aims to legally compel government to appropriate and distribute mostly abandoned lands to those living in poverty [290]. The lands are often rehabilitated into cooperative farms that are managed sustainably by families [291]. Correlating human rights protections with climate change mitigation and impacts [292] may prove useful as an emerging strategy for movements such as the MST to extend their power and redress unjust laws and labor practices, including those that are equated with slavery [293,294].

Most commonly, slave labor in Brazil is used to clear land for agriculture. For example, in the soy frontier of Mato
Grosso and Pará, for the years 2003 and 2004, almost 8,700 incidences of slavery were reported by government [295]. To counter this, initiatives could legally organize around the concept of a 'just transitions law' to realize a lower carbon economy by bringing together environmental and labor laws in approaches that link worker-based human trafficking and rights organizations [296] with climate change legislation, sustainability practices, and Indigenous and small farmer land tenure security [297]. As yet, such policies remain under-explored in legal literature [298] but may over time coalesce to bring pressure to agribusiness producers, multinational buyers, and mega-supermarket chains to adhere to better labor, sustainable production, and transparency practices.

Other initiatives, though presenting their own integrity issues, are a step toward advancing sustainability in multidirectional supply chains. These include fair trade [299] and organic certification practices [300], Indigenous food production systems [301] and carbon security initiatives. In 2018, Netherlands-based Louis Dreyfus Company announced it will become the first major commodity trader to stop buying soy from newly deforested land specifically in the Cerrado [302]. However, there are few transparent methods with which to trace the integrity of supply chains. For example, major associations like the Round Table on Responsible Soy (RTRS) certify using a book and claim chain of custody system [303] that offers little transparency.

Another sector gaining traction is the sustainable, responsible and impact (SRI) investment sector, a growing area which has received an influx of money since the Paris Climate Agreement. The capacity of SRI lies in both divestment and reinvestment. Though reinvestments are vulnerable to greenwashing-for example, consider the criticisms levelled at the RTRS [304] — the SRI sector is an indicator of the public's desire to support sustainability goals.

Reallocation of capital, together with changing public attitude is, however, becoming more influential in reforming agriculture and fighting climate change [305,306]. For example, at the 2014 UN Climate Summit, Norway, Germany and the UK pledged to support public procurement policies for sustainably sourced products like soy and to encourage deforestation-free supply chains [307], and Norway's action plan presented by parliament in 2016 argued the government need exercise due care for the protection of biodiversity in its global pension fund investments [308]

What matters with these sorts of commitments is policy longevity. For example, in 2015, Norway paid \$1 billion to Brazil [309] for fulfilling a 2008 agreement between the two countries to prevent deforestation. At the time, the deal [310] resulted in the largest global emissions cut over the lifespan of the agreement [311]. However the victory was short-lived, and came at the expense of Cerrado lands and waters [302]. This scenario is useful to examine for two reasons. Firstly, with deforestation again soaring [312-314], this scenario illustrates how Brazil leverages its sovereign natural resources for monetary gain. Secondly, international attention has always concentrated on saving the iconic 
Amazon rainforest, whereas the largely unknown Cerrado suffers from an image problem that doesn't represent the popular vision of a carbon sink or priority conservation area [315]. Though it's possible that the Cerrado's public profile has been marginally raised through the recently publicized 'Cerrado Manifesto', there is no evidence to suggest that this market pledge [316] is anything more than corporate greenwashing [317].

One measure which could prove useful as an ethical evaluation metric is virtual water. Brazil is a sizeable exporter of virtual water [318]. Though the water footprint of crop production for export varies greatly between regions in Brazil, the concept could be used to establish new responsibility guidelines. Industrial animal farming (and its relationship to imported feed) is the most water-intensive and water polluting form of meat production, therefore, calculating the virtual water footprints of nations by including the impact of livestock feed imports might be another avenue through which to introduce a resource consumption cap. Additionally, if large consumers such as China and the EU withdrew their oilseed commitments under the current WTO Agreement on Agriculture, they could potentially be freed up to establish domestic production of more varied livestock feeds (such as the EU produced in the 1990s) without policy limitations [319].

There is an emerging view that replicable models of sustainable management of tropical forested lands may be found within the knowledge systems of contemporary Indigenous peoples [320]. Indigenous knowledge is increasingly being recognized as an important source of knowledge in regard to climate change and adaptation [99,321]. This suggests that climate change is emerging as a battleground strategy that may also be used to strengthen Indigenous rights and protections. Indigenous land management systems are increasingly considered a legitimate right of Indigenous people, and their information and knowledge systems for managing climate change are becoming progressively more valued [322,323]. In Brazil, a 37-year analysis determined that Indigenous land management techniques of the Xavante were responsible for rebuilding ecological integrity and sustaining vegetation recovery in Cerrado regions that had been deforested by agribusiness [324]. Several Indigenous initiatives [325] are active in combating issues associated with mono-cropping-including deforestation, biodiversity loss, water pollution, and the erosion of rights. These movements may be further aided by the concept of intergenerational equity [326] that is embedded in modern international environmental law. Legal guidelines established by the World Heritage Convention also define a State's obligation to protect and conserve cultural and natural heritage for future generations [327]. The International Union for Conservation of Nature Environmental Law Centre [255,328] has developed a body of conservation tools and resources for establishing and strengthening this legal framework [329].

Biodiversity conservation, recognized as crucial for mitigating climate change [330], is beginning to receive renewed attention. At the 2018 UN Conference on Biodiversity, a coalition of Indigenous groups from across Latin America called for the creation of the world's largest protected area to stretch from Mexico through Brazil. Another legal proposition has proposed extending the country's soy moratorium in the Amazon to include the Cerrado region [331]. The proposal would prohibit providing credit or buying soybeans from producers who grow in deforested areas. Long-standing constitutional amendments bills such as PEC 115/95 and PEC $504 / 2010$ also propose the Cerrado be considered national heritage. It is improbable that any of these measures will be adopted anytime soon by congress, and with Bolsonaro leading Brazil it is imperative that new strategies proposing systemic environmental protections be pushed.

Actions that confront climate change may be rooted in ethical issues of responsibility, yet they present a direct threat to the fundamental values of neoliberal capitalism. As such, they stand facing the "perfect moral storm" [332]—confronted by political philosophies that obfuscate science, fail to recognize the value of non-human life, prioritize the commodity value of nature, and operate in climates of corruption and under the judicial auspices of business as usual [237,333]. Still, in the near future, agribusiness may be challenged by what oil corporations are dealing with now-where municipal- and state-level legal efforts, sustained activism, and an evolution in communications campaigning are bringing more pressure to bear on industry's role in climate change.

Brazil's Intended Nationally Determined Contributions (INDC), pledged at the Paris Climate Conference, focused on the agricultural sector's commitments to mitigate global warming, $[334,335]$ yet achievements fall below stated targets $[336,337]$. Climate change mitigation protocols exist for designing, assessing and reporting national and sub-national goals in relation to reducing agriculture's GHG emissions [338], and in some countries, climate change litigation has served as a successful strategy with which to enforce targets [241]. Brazil may, theoretically, be challenged to uphold its international pledges through the constitutional principle of sustainable development $[339,340]$ in accordance with the $\mathrm{Na}$ tional Policy for Climate Change (NPCC) [341,342]. However, the manipulation of data [336], the abandonment of deforestation control policies, President Jair Bolsonaro's threat to withdraw from the Climate Paris Accord [343], and weighted political support for predatory agricultural practices have derailed Brazil's contribution to a $>2^{\circ} \mathrm{C}$ world [344].

Environmental protection measures can be circumvented through loopholes in forestry cover mandates and emissions trade-offs, codes, and tax incentive schemes such as Brazil's Payment for Environmental Services, Environmental Reserve Quotas, Private Natural Heritage Reserves, the Forest Code (FC), the Ecological Value Added Tax, or the Low Carbon Agriculture (ABC) program. In some cases, these schemes are already used to manipulate forest cover quotas by preserving vegetation fragments where alternative use value is low [345] to enable private deforestation to legally occur [346], or to support measures that promote businessas-usual approaches to farming. For example, the National Policy on Integration of Farming, Livestock and Forestry law 
[347], which seeks to mitigate deforestation, is managed under the $A B C$ program. The ABC is problematic because early on its policies were relaxed to allow farmers and ranchers to use $A B C$ credit lines to purchase cattle, remove tree stumps from recently deforested lands, and increase the number of cattle that ranchers can graze per hectare. Thus, ABC may lead to further deforestation in remote and vegetated areas through incentivizing predatory land speculation [348,349]. In another case, environmental protections were quashed through a decision by the Supreme Court to overrule a municipal regulation that had banned fire as a sugarcane harvesting method [342]. These examples underscore that Brazil's environmental protections [350] are frequently undermined by agribusiness interests, corruption, and violence [351].

Brazil is the most threatening place in the world to advocate for territorial and environmental rights. Between 2002 and 2013, at least 448 environmentalists were killed throughout the country, a number which equals approximately half of all environmentalists murdered globally during the same period. Around $40 \%$ of those were Indigenous peoples involved in disputes over natural resources [352]. In 2016, Brazil again ranked first in deaths over land rights disputes and the protection of the environment, holding the position for the 14th consecutive year, with 49 recorded deaths for 2016 [353]. In the time period since 2000, about a million families have been threatened by agribusiness conflicts [354]. With the political intolerance and violent threats continually being levelled at Brazil's Indigenous and landless populations, and what essentially amounts to the elimination of Brazil's Ministry for the Environment, multipronged, ethics-based legal pressure is one of the few avenues that remain open as a viable means of fighting for the environmental protection of the Cerrado and its peoples.

\section{Conclusion}

This paper has reviewed the ecological and hydrological importance of the Cerrado and explicated how the biome is at risk due to massive land-use change produced by

\section{References and Notes}

[1] Myers N, Mittermeier RA, Mittermeier CG, Da Fonseca GA, Kent J. Biodiversity hotspots for conservation priorities. Nature. 2000;403(6772):853. Available from: http://www.ncbi.nlm.nih.gov/ pubmed/10706275.

[2] Union of Concerned Scientists. The Importance of Brazil's Cerrado: Fact Sheet; 2016. Available from: https://www.ucsusa.org/sites/default/files/attach/2016/11/cerradofact-sheet-ucs-october-2016.pdf.

[3] Guilherme J, Ispn C, Napolitano J, Ceolin R, Araújo R, Bastos S, et al.. Ecosystem Profile Cerrado Biodiversity Hotspot; 2017. Available from: http://www.cepf.net/where_we_work/regions/ south_america/cerrado/Pages/default.aspx.

[4] Klink CA, Machado RB. Conservation of the Brazilian Cerrado. Conservation Biology. 2005;19(3):707-713. doi:10.1111/j.15231739.2005.00702.x. large-scale, mechanized soy production and other forms of agribusiness that drives deforestation on an immense scale. It describes how this has changed hydrological patterns and threatens water security in key ways. It has illustrated a political ecology at a national level that engineers agricultural policies to disproportionately favor large-scale landholders at the expense of environmental integrity and human security. It considers social and economic ramifications that trace back to changes in water resources and rainfall patterns. It exposes how the market and state act in concert to channel wealth through a globalized agribusiness culture, and finally, suggests considering a pathway forward that confronts the challenges presented by the 'perfect storm' of oligarchical political control and climate change, which threaten sustainability as never before.

Brazil is projected to experience the largest global increase in agricultural production over the next four decades [355]. It is unclear how simultaneous changes in the Cerrado's native vegetation structure, precipitation patterns, and climate change will interact to affect land and water resources over time as a result of the impact of soy and other large-scale agribusiness enterprises. Evidence suggests that reduced deforestation and increased agricultural production can occur simultaneously in Brazil's frontier region, but that this is contingent on policies that promote intensification on already-cleared lands while restricting deforestation [356]. It is doubtful, however, that government- and industry-led policies will control deforestation as the market begins to favor another boom in expansion. The country may be able to meet demands for increased crop acreage through 2040 by intensification, however it is unlikely this will be achieved without further disruption to rainfall patterns or ecological stability. With Brazil holding $12-16 \%$ of all freshwater reserves globally, protecting water integrity must be considered a matter of urgent national security, one that must be recognized as a complex fabric of interrelated causes, vulnerability, and impacts associated with globalization and Brazil's agribusiness industry.

[5] Brazilian Ministry for the Environment (Ministério do Meio Ambiente. O Bioma Cerrado. Available from: http://www.mma.gov.br/biomas/ cerrado.

[6] Aguiar S, Santos IDS, Arêdes N, Silva S. Biome-networks: Information and communication for sociopolitical action in eco-regions. Ambiente \& Sociedade. 2016;19(3):231-248. doi:10.1590.

[7] Oliveira PTS, Nearing MA, Moran MS, Goodrich DC, Wendland E, Gupta HV. Trends in water balance components across the Brazilian Cerrado. Water Resources Research. 2014;50(9):7100-7114. doi:10.1002/2013WR015202.

[8] Helfand SM, Rada NE, Magalhães MM. Brazilian Agriculture: Is it all about the Large Farms? EuroChoices. 2017;16(1):17-22. doi:10.1111/1746-692X.12145.

[9] Carneiro F, Costa K. The expansion of soybean production in the Cerrado Paths to sustainable territorial occupation, land use and production. Available from: http://www.inputbrasil.org/wpcontent/uploads/2016/11/The-expansion-of-soybean-production- 
in-the-Cerrado_Agroicone_INPUT.pdf.

[10] MacDonald M, Simon J. Cattle, soyanization, and climate change. Brazil's agricultural revolution. Brighter Green. 2011; Available from: http://www.brightergreen.org/files/brazil_bg_pp_2011.pdf.

[11] Oliveira G, Hecht S. Sacred groves, sacrifice zones and soy production: globalization, intensification and neo-nature in South America. The Journal of Peasant Studies. 2016;43(2):251-285. doi:10.1080/03066150.2016.1146705

[12] Masuda T, Goldsmith PD, et al. China's meat and egg production and soybean meal demand for feed: An elasticity analysis and longterm projections. International Food and Agribusiness Management Review. 2012;15(3):33-54. Available from: https://www.ifama.org/ resources/Documents/v15i3/Masuda-Goldsmith.pdf.

[13] Nascimento L. Grão sustentará crescimento de carnes na década; 2012. Available from: https://www.agrolink.com.br/.

[14] How the global oilseed and grain trade works. Southwest Harbor, ME, US: US Soybean Export Council; 2008. Available from: http://www.unitedsoybean.com.

[15] Neill C, Coe MT, Riskin SH, Krusche AV, Elsenbeer H, Macedo $\mathrm{MN}$, et al. Watershed responses to Amazon soya bean cropland expansion and intensification. Philosophical Transactions of the Royal Society B: Biological Sciences. 2013;368(1619):20120425. doi:10.1098/rstb.2012.0425.

[16] Resck DVS. Agricultural intensification systems and their impact on soil and water quality in the Cerrados of Brazil. Soil Quality and Agricultural Sustainability. 1998;pp. 288-300.

[17] Weis T. The ecological hoofprint: The global burden of industrial livestock. Zed Books Ltd.; 2013.

[18] Hamerschlag K, Lappe A, Malkan S. Spinning Food: How Food Industry Front Groups and Covert Communication are Shaping the Story of Food. Friends of the Earth. 2015; Available from: https://1bps6437gg8c169i0y1drtgz-wpengine.netdna-ssl.com/wpcontent/uploads/2017/legacy/FOE_SpinningFoodReport_8-15.pdf.

[19] Weis AJ, Weis T. The global food economy: The battle for the future of farming. Zed Books; 2007.

[20] Bittle S, Snider L, Tombs S, Whyte D. Revisiting Crimes of the Powerful: Marxism, Crime and Deviance. Routledge; 2018.

[21] Transnational corporations and land speculation in Brazil. Network for Social Justice and Human Rights; 2018. Available from: https://1bps6437gg8c169i0y1drtgzwpengine.netdna-ssl.com/wp-content/uploads/2018/04/ transnational_corporations_and_land_speculation_in_brazil.pdf.

[22] Altieri MA, Pengue WA. GM Soya Disaster in Latin America. ISIS Report. 2005;6(09):05. Available from: http://www.i-sis.org.uk/SDILA. php.

[23] Mano A. Brazil's Mato Grosso leads push for GM-free soy. Reuters. 2017; Available from: https://www.reuters.com/article/brazilgrains-gmo/brazils-mato-grosso-leads-push-for-gm-free-soyidUSL1N1IA0KW.

[24] Deforestation in Brazilian Soy Supply Chain: Market Access Risk from a Growing Share of Sourcing Commitments. Washington, DC, USA: Chain Reaction Research; 2017. Available from: https://chainreactionresearch.com/report/deforestation-in-thebrazilian-soy-supply-chain-market-access-risk-from-a-growingshare-of-sourcing-commitments/.

[25] del Carmen Vera-Diaz M, Kaufmann RK, Nepstad DC. The environmental impacts of soybean expansion and infrastructure development in Brazil's Amazon basin. Tufts University; 2009. Available from: http://www.ase.tufts.edu/gdae/Pubs/wp/0905TransportAmazon.pdf.

[26] Fearnside PM. Soybean cultivation as a threat to the environment in Brazil. Environmental Conservation. 2001;28(1):23-38. doi:10.1017/S0376892901000030.

[27] Marinho C, Martins F, Amaral Júnior A, Gonçalves L, dos Santos O, Alves D, et al. Genetically modified crops: Brazilian law and overview. Genetics and Molecular Research. 2014;13(3):52215240. doi:10.4238/2014.July.7.15.

[28] 20 years of GM soy in the Southern Cone of Latin America, 20 reasons for a definitive ban; 2017. Available from: https://www.grain.org/media/W1 siZilsljlwMTcvMDUvMTcvMTFfMz VfNTZfMjQ4X1Bvc3RIcl9FTI9Tb3lhLnBkZiJdXQ.

[29] Richards P, Pellegrina H, VanWey L, Spera S. Soybean devel- opment: The impact of a decade of agricultural change on urban and economic growth in Mato Grosso, Brazil. PLoS one. 2015;10(4):e0122510. doi:10.1371/journal.pone.0122510.

[30] Hunke P, Mueller EN, Schröder B, Zeilhofer P. The Brazilian Cerrado: assessment of water and soil degradation in catchments under intensive agricultural use. Ecohydrology. 2015;8(6):11541180. doi:10.1002/eco.1573

[31] Challenges and opportunities for conservation, agricultural production and social inclusion in the Cerrado biome. San Francisco, CA, USA: CEA Consulting; 2016. Available from: http://www.climateandlandusealliance.org/wp-content/uploads/ 2016/09/Cerrado-biome-apppendix_funding-sources.pdf.

[32] Conclusions and main policy recommendation. In: The State of the World's Land and Water Resources for Food and Agriculture: Managing systems at risk. Oxford: UK: Food and Agriculture Organization of the United Nations; 2011. Available from: http://www.fao.org/docrep/017/i1688e/i1688e08.pdf.

[33] Peine EK. In: Trading on pork and beans: agribusiness and the construction of the brazil-china-soy-pork commodity complex. Springer 2013. pp. 193-210. doi:10.1007/978-94-007-6274-9_10.

[34] Galloway JN, Burke M, Bradford GE, Naylor R, Falcon W, Chapagain AK, et al. International trade in meat: The tip of the pork chop. AMBIO: A Journal of the Human Environment. 2007;36(8):622-629. Available from: https://bioone.org/journals/AMBIO-A-Journal-of-theHuman-Environment/volume-36/issue-8/0044-7447(2007)36[622: ITIMTT]2.0.CO;2/International-Trade-in-Meat--The-Tip-of-thePork/10.1579/0044-7447(2007)36[622:ITIMTT]2.0.CO;2.short.

[35] Brown LR. Outgrowing the Earth: the food security challenge in an age of falling water tables and rising temperatures. Routledge; 2012. Available from: http://www.earth-policy.org/books/out.

[36] Peine E. The private state of agribusiness: Brazilian soy on the frontier of a new food regime [PhD Thesis]. Cornell University. Ithaca, NY, USA; 2009. Available from: https://hdl.handle.net/1813/14031.

[37] McMichael P. Banking on agriculture: a review of the World Development Report 2008. Journal of Agrarian Change. 2009;9(2):235-246. doi:10.1111/j.1471-0366.2009.00203.x.

[38] Veltmeyer $\mathrm{H}$. The future of food and challenges for agriculture in the 21st century; 2017. Available from: www.elikadura21.eus.

[39] Petras J, Veltmeyer H. Agro-extractivism: The agrarian question of the 21st century. In: Extractive imperialism in the Americas: Capitalism's new frontier. Brill; 2014. pp. 62-100. doi:10.1163/9789004268869.

[40] Bohn S. Quasi-post-neoliberal Brazil: Social Change Amidst Elite Adaptation and Metamorphosis. In: North LL, Clark TD, editors. Dominant Elites in Latin America. Springer; 2018. pp. 57-92. doi:10.1007/978-3-319-53255-4_3.

[41] Oliveira GdL, Schneider M. The politics of flexing soybeans: China, Brazil and global agroindustrial restructuring. The Journal of Peasant Studies. 2016;43(1):167-194. doi:10.1080/03066150.2014.993625.

[42] loris AA. Cracking the nut of agribusiness and global food insecurity: In search of a critical agenda of research. Geoforum. 2015;63:1-4 doi:10.1016/j.geoforum.2015.05.004.

[43] McMichael P. Feeding the world: agriculture, development and ecology. Socialist Register. 2007;43(43). Available from: https: //socialistregister.com/index.php/srv/article/view/5863.

[44] Weis T. The accelerating biophysical contradictions of industrial capitalist agriculture. Journal of agrarian change. 2010;10(3):315-341. doi:10.1111/j.1471-0366.2010.00273.x.

[45] Lathuillière MJ, Coe MT, Castanho A, Graesser J, Johnson MS Evaluating Water Use for Agricultural Intensification in Southern Amazonia Using the Water Footprint Sustainability Assessment. Water. 2018;10(4):349. doi:10.3390/w10040349.

[46] Pinto HS, Assad ED. Aquecimento global e cenários futuros da agricultura brasileira. Campinas, SP, Brazil: Embrapa; 2008. Available from: https://secured-static.greenpeace.org/brasil/PageFiles/ 3580/Eduardo_Assadi_EMBRAPA.pdf.

[47] Arvor D, Daugeard M, Tritsch I, De Mello-Thery NA, Thery H, Dubreuil V. Combining socioeconomic development with environmental governance in the Brazilian Amazon: The Mato Grosso agricultural frontier at a tipping point. Environment, Development and Sustainability. 2018;20(1):1-22. doi:10.1007/s10668-016-9889- 
[48] Malhado ACM, Pires GF, Costa MH. Cerrado conservation is essential to protect the Amazon rainforest. Ambio. 2010;39(8):580-584. doi:10.1007/s13280-010-0084-6.

[49] Strassburg BB, Brooks T, Feltran-Barbieri R, Iribarrem A, Crouzeilles $\mathrm{R}$, Loyola R, et al. Moment of truth for the Cerrado hotspot. Nature Ecology \& Evolution. 2017;1(4):0099. doi:10.1038/s41559-0170099.

[50] Lang M, Mokrani D. Beyond development: alternative visions from Latin America. Transnational Inst.; 2013. Available from: https: //www.tni.org/files/download/beyonddevelopment_complete.pdf.

[51] Ioris AAR. The politico-ecological economy of neoliberal agribusiness: displacement, financialisation and mystification. Area. 2015;48(1):84-91. doi:10.1111/area.12240.

[52] Bennett NJ, Roth R, Klain SC, Chan K, Christie P, Clark DA, et al. Conservation social science: Understanding and integrating human dimensions to improve conservation. Biological Conservation. 2017;205:93-108. doi:10.1016/j.biocon.2016.10.006.

[53] Martin JL, Maris V, Simberloff DS. The need to respect nature and its limits challenges society and conservation science. Proceedings of the National Academy of Sciences. 2016;113(22):6105-6112. doi:10.1073/pnas.1525003113.

[54] van Berkum S, Bindraban PS. Towards sustainable soy: an assessment of opportunities and risks for soybean production based on a case study Brazil. LEI Wageningen UR; 2008. Available from: https://core.ac.uk/download/pdf/29258395.pdf.

[55] Eloy L, Aubertin C, Toni F, Lúcio SLB, Bosgiraud M. On the margins of soy farms: traditional populations and selective environmental policies in the Brazilian Cerrado. The Journal of Peasant Studies. 2016;43(2):494-516. doi:10.1080/03066150.2015.1013099.

[56] Hafner R. Environmental justice and soy agribusiness. New York: Earthscan/Routledge; 2018. Available from: http://www.worldcat.org/title/environmental-justice-and-soyagribusiness/oclc/1038711895\&referer=brief_results.

[57] Phillips N, Sakamoto L. Global production networks, chronic poverty and 'slave labour'in Brazil. Studies in Comparative International Development. 2012;47(3):287-315. doi:10.1007/s12116-012-9101-z.

[58] Gardner TA, Benzie M, Börner J, Dawkins E, Fick S, Garrett R, et al. Transparency and sustainability in global commodity supply chains. World Development. 2018;doi:10.1016/j.worlddev.2018.05.025.

[59] Shankland A, Gonçalves E. Imagining agricultural development in South-South cooperation: the contestation and transformation of ProSAVANA. World Development. 2016;81:35-46. doi:10.1016/j.worlddev.2016.01.002.

[60] The analysis was defined by a series of keyword searches that led to identify the themes and recurring ideas examined. Firstly, a Google Scholar search of English language articles was conducted using the keywords: Brazilian Cerrado, hydrology. The first 500 results yielded by Google Scholar (of 12,000 returned results sorted by relevance/most recent date of publication) were primarily concerned with evaluating conservation measures: climate changes, pesticide leaching, water levels, carbon sequestration and land use $(93 \%)$. When land use was added to the search, the top 500 results yielded commonalities in regional hydrology issues (e.g. evapotranspiration), agricultural frontier expansion, carbon stocks, emissions, and deforestation. Soy was identified as a contributing factor in a majority $(96 \%)$ of search results. The search was then modified to soy, agricultural expansion, Brazilian cerrado, hydrology. Of the top 500 results analyzed, approximately $8 \%$ were productivist in nature, and of those approximately half were favorable toward productivist discourse. With the identification of these broad themes, a wider literature search was conducted through a normative Google search to include non-academic reports, websites, and media to expand the discursive content. The search soy, agricultural expansion, Brazilian cerrado, hydrology, yielded productivist pro-growth discourse in approximately $20 \%$ of the top 500 results analyzed. When the search was amended to replace expansion with intensification, progrowth discourse was prevalent in approximately $50 \%$ of articles the top 500 search results reviewed, and of those, approximately $50 \%$ were unfavorable to pro-growth discourse due to environmental concerns.

[61] Veldman JW, Buisson E, Durigan G, Fernandes GW, Le Stradic S,
Mahy G, et al. Toward an old-growth concept for grasslands, savannas, and woodlands. Frontiers in Ecology and the Environment 2015;13(3):154-162. doi:10.1890/140270.

[62] Grecchi RC, Gwyn QHJ, Bénié GB, Formaggio AR. Assessing the spatio-temporal rates and patterns of land-use and land-cover changes in the Cerrados of southeastern Mato Grosso, Brazil. International journal of remote sensing. 2013;34(15):5369-5392. doi:10.1080/01431161.2013.788798.

[63] Beuchle R, Grecchi RC, Shimabukuro YE, Seliger R, Eva HD, Sano $\mathrm{E}$, et al. Land cover changes in the Brazilian Cerrado and Caatinga biomes from 1990 to 2010 based on a systematic remote sensing sampling approach. Applied Geography. 2015;58:116-127. doi:10.1016/j.apgeog.2015.01.017.

[64] Spera SA, Galford GL, Coe MT, Macedo MN, Mustard JF. Land-use change affects water recycling in Brazil's last agricultural frontier. Global change biology. 2016;22(10):3405-3413 doi:10.1111/gcb.13298.

[65] Rudorff B, Risso J. Geospatial Analyses of the Annual Crops Dynamic in the Brazilian Cerrado Biome; 2015. Available from: http://biomas.agrosatelite.com.br/img/Geospatial_analyses of_the_annual_crops_dynamic_in_the_brazilian_Cerrado_biome.pdf.

[66] Jepson W, Brannstrom C, Filippi A. Access regimes and regional land change in the Brazilian Cerrado, 1972-2002. Annals of the Association of American Geographers. 2010;100(1):87-111. doi:10.1080/00045600903378960.

[67] Gusso A, Ducati JR, Bortolotto VC. Analysis of soybean cropland expansion in the southern Brazilian Amazon and its relation to economic drivers. Acta Amazonica. 2017;47(4):281-292. doi:10.1590/1809-4392201700543.

[68] Arantes AE, Ferreira LG, Coe MT. The seasonal carbon and water balances of the Cerrado environment of Brazil: Past, present, and future influences of land cover and land use. ISPRS Journal of Photogrammetry and Remote Sensing. 2016;117:66-78. doi:10.1016/j.isprsjprs.2016.02.008.

[69] Batlle-Bayer L, Batjes NH, Bindraban PS. Changes in organic carbon stocks upon land use conversion in the Brazilian Cerrado: a review. Agriculture, ecosystems \& environment. 2010;137(1-2):4758. doi:10.1016/j.agee.2010.02.003.

[70] Brack D, Bailey R. Ending global deforestation: Policy options for consumer countries. London, UK: Chatham House; 2013. Available from: https://www.forest-trends.org/wp-content/uploads/imported/ Brack_Deforestation_Programme_Report_FINAL.pdf.

[71] Carranza T, Balmford A, Kapos V, Manica A. Protected Area Effectiveness in Reducing Conversion in a Rapidly Vanishing Ecosystem: The Brazilian Cerrado. Conservation Letters. 2013 jul;7(3):216-223. Available from: https://doi.org/10.1111\%2Fconl. 12049. doi:10.1111/conl.12049.

[72] Espírito-Santo MM, Leite ME, Silva JO, Barbosa RS, Rocha AM, Anaya FC, et al. Understanding patterns of land-cover change in the Brazilian Cerrado from 2000 to 2015. Philosophical Transactions of the Royal Society B: Biological Sciences. 2016;371(1703):20150435. doi:10.1098/rstb.2015.0435.

[73] Oliveira G, Hecht S, editors. Soy Production in South America: Globalization and New Agroindustrial Landscapes. The Journal of Peasant Studies. Taylor \& Francis; 2016. Available from: https://www.tandfonline.com/toc/fjps20/43/2.

[74] de L T Oliveira G, Hecht SB, editors. Soy, Globalization, and Environmental Politics in South America. Routledge; 2017.

[75] Wolford W. Environmental justice and the construction of scale in Brazilian agriculture. Society and Natural Resources. 2008;21(7):641-655. doi:10.1080/08941920802096432.

[76] Seed O, News G. Oilseed \& Grain Trade. Soy Facts; 2017. Available from: http://www.oilseedandgrain.com/soy-facts.

[77] International WW. The Growth of Soy Impacts and Solutions 2014. Available from: http://awsassets.panda.org/downloads/ wwf_soy_report_final_feb_4_2014_1.pdf.

[78] Cattelan AJ, Dall'Agnol A. The rapid soybean growth in Brazil. OCL. 2018;25(1):D102. doi:10.1051/ocl/2017058.

[79] Altieri MA, Pengue W. GM soybean: Latin America's new colonizer Seedling. 2006;1:13-17. Available from: https:/www.grain.org/ article/entries/588-gm-soybean-latin-america-s-new-colonizer.

[80] Samora R. Brazil to pass U.S. as world's largest 
soy producer in 2018. Reuters. 2018; Available from: https://www.reuters.com/article/us-brazil-soy-usa/brazil-to-passu-s-as-worlds-largest-soy-producer-in-2018-idUSKBN1IC2IW.

[81] Challenges and Opportunities for Conservation, Agricultural Production, and Social Inclusion in the Cerrado Biome. San Francisco, CA, USA: CEA Consulting; 2016. Available from: http://www.climateandlandusealliance.org/wp-content/uploads/ 2016/09/Cerrado-biome-apppendix_water-and-climate.pdf.

[82] Silva J, Farinas M, Felfili J, Klink C. Spatial heterogeneity, land use and conservation in the cerrado region of Brazil. Journal of Biogeography. 2006;33(3):536-548. doi:10.1111/j.1365-2699.2005.01422.x.

[83] de Castro SS, de Queiroz Neto JP. Soil erosion in Brazil from coffee to the present-day soy bean production. Developments in Earth Surface Processes. 2009;13:195-221. doi:10.1016/S09282025(08)10011-6.

[84] Conflitos no Campo Brasil 2016. Goiania, GO, Brazil: Comissão Pastoral da Terra; 2016. Available from: https://www.cptnacional.org. br/index.php/component/jdownloads/download/41-conflitos-nocampo-brasil-publicacao/14061-conflitos-no-campo-brasil-2016.

[85] Wantzen KM, Siqueira A, da Cunha CN, Pereira de Sá MdF. Streamvalley systems of the Brazilian Cerrado: impact assessment and conservation scheme. Aquatic Conservation: Marine and Freshwater Ecosystems. 2006;16(7):713-732. doi:10.1002/aqc.807.

[86] Pinto Dias LC, Macedo MN, Costa MH, Coe MT, Neill C. Effects of land cover change on evapotranspiration and streamflow of small catchments in the Upper Xingu River Basin, Central Brazil. Journal of Hydrology: Regional Studies. 2015;4:108-122. doi:10.1016/j.ejrh.2015.05.010.

[87] Macedo M, Coe M, Soares-Filho B, Ferreira L, Panday P. Hydrological impacts of land-use change and agricultural policy in the Brazilian Cerrado. In: AGU Fall Meeting Abstracts; 2013. Available from: http://adsabs.harvard.edu/abs/2013AGUFM.H51E1240M.

[88] da Silva NM, Angeoletto F, Santos JW, Paranhos Filho AC, Vacchiano MC, Bohrer JF, et al. The negative influences of the new brazilian forest code on the conservation of riparian forests. European Journal of Ecology. 2017;3(2):116-122. doi:10.1515/eje-2017-0019.

[89] coalition: Aidenvironment / Climate Advisers / Profundo CRR. BrasilAgro: Cerrado Deforestation Could Reduce Farmland Value, Put Soy Revenue at Risk; 2017. Available from: www. chainreactionresearch.com.

[90] of Agriculture M. Art. 1, $\S 1$ do Decreto 8447/15 (Agricultural Development Plan Matopiba (PDA-MATOPIBA); 2015. Available from: https://www.jusbrasil.com.br/topicos/35232341/paragrafo-1artigo-1-do-decreto-n-8447-de-06-de-maio-de-2015.

[91] Teixeira PF, Cerdas VG. Impacts of agribusiness expansion in the Matopiba region: Communities and the environment. Erasmus University. Rotterdam, Netherlands; 2017. Available from: https://thesis.eur.nl/pub/41754.

[92] Lahsen M, Bustamante MM, Dalla-Nora EL. Undervaluing and overexploiting the Brazilian Cerrado at our peril. Environment: science and policy for sustainable development. 2016;58(6):4-15. doi:10.1080/00139157.2016.1229537.

[93] Noojipady P, Morton CD, Macedo NM, Victoria CD, Huang C, Gibbs $\mathrm{KH}$, et al. Forest carbon emissions from cropland expansion in the Brazilian Cerrado biome. Environmental Research Letters. 2017;12(2):025004. doi:10.1088/1748-9326/aa5986.

[94] de Goes Calmon DP. The politics of contemporary agrarian frontiermaking: insights from Matopiba region, Brazil. Rotterdam, Netherlands; 2017. Available from: hdl.handle.net/2105/41754.

[95] Johnsson RMF. Water Resources Management in Brazil: Challenges and New Perspectives. World Bank Water. 2014; Available from: https://engineering.columbia.edu/files/engineering/designwater-resource02.pdf.

[96] Brazil: Irrigated crop calendar. FAO; 2012. Available from: http://www.fao.org/3/a-i6583e.pdf.

[97] AQUASTAT Brazil: FAO's Information System on Water and Agriculture. FAO/ANA; 2016. Available from: http://www.fao.org/nr/water/ aquastat/countries_regions/Profile_segments/BRA-IrrDr_eng.stm.

[98] Brazil could increase Irrigated Crop Acreage 65\% in Six Years. Soybean And Corn Advisor; 2018. Available from: http://www.soybeansandcorn.com/news/Mar29_18-BrazilCould-Increase-Irrigated-Crop-Acreage-65-in-Six-Years.
[99] The future of food and agriculture: Trends and challenges. FAO; 2017. Available from: www.fao.org/publications.

[100] Prager A, Milhorance F. Cerrado: Agribusiness may be killing Brazil's 'birthplace of waters'. Mongabay. 2018 Mar 19; Available from: https://news.mongabay.com/2018/03/cerrado-agribusinessmay-be-killing-brazils-birthplace-of-waters/.

[101] Yamada C. Shared natural resources: First Special Rapporteur report on shared natural resources: outlines; 2003. Available from: http://legal.un.org/ilc/documentation/english/a_cn4_533.pdf.

[102] Jawerth N. Out of sight, but in their minds: Brazil and its neighbours work together to protect one of the world's largest groundwater reservoirs. IAEA Bulletin. 2015;pp. 27. Available from: https://www.iaea.org/sites/default/files/56105912627.pdf.

[103] Kruskal J. Regional Water Security Threatened by Stalled South America Agreement. International Policy Digest; 2016. Available from: http://intpolicydigest.org/2016/11/14/regional-water-securitythreatened-stalled-south-america-agreement/.

[104] Sindico F, Hirata R, Manganelli A. The Guarani Aquifer System: From a Beacon of hope to a question mark in the governance of transboundary aquifers. Journal of Hydrology: Regional Studies. 2018;doi:10.1016/j.ejrh.2018.04.008.

[105] Custodio E. Intensive groundwater development. In: Rethinking Water and Food Security. CRC Press; 2010. pp. 259-298. doi:10.1201/b10541-20.

[106] Richey AS, Thomas BF, Lo MH, Reager JT, Famiglietti JS, Voss K, et al. Quantifying renewable groundwater stress with GRACE. Water resources research. 2015;51(7):5217-5238. doi:10.1002/2015WR017349.

[107] The Perils of the Global Soy Trade: Economic, Environmental and Social Impacts - Soybean - Genetically Modified Crops. Food and Water Watch, Water Europe; 2011. Available from: https://www.scribd.com/document/48362949/The-Perils-of-theGlobal-Soy-Trade-Economic-Environmental-and-Social-Impacts.

[108] Lucas M, Wendland E. Recharge estimates for various land uses in the Guarani Aquifer System outcrop area. Hydrological Sciences Journal. 2016;61(7):1253-1262. doi:10.1080/02626667.2015.1031760.

[109] Klink CA, Machado RB. Conservation of the Brazilian cerrado. Conservation biology. 2005;19(3):707-713. doi:10.1111/j.15231739.2005.00702.x.

[110] Meirelles M, Franco A, Farias S, Bracho R. Evapotranspiration and plant-atmospheric coupling in a Brachiaria brizantha pasture in the Brazilian savannah region. Grass and Forage Science. 2011;66(2):206-213. doi:10.1111/j.1365-2494.2010.00777.x.

[111] Wohl E, Barros A, Brunsell N, Chappell NA, Coe M, Giambelluca T, et al. The hydrology of the humid tropics. Nature Climate Change. 2012;2(9):655. doi:10.1038/nclimate1556.

[112] Xu Zx, Li L, Zhao J. A distributed eco-hydrological model and its application. Water Science and Engineering. 2017;10(4):257-264. doi:10.1016/j.wse.2017.12.007.

[113] Biswas AK, Cordeiro NV, Braga BP, Tortajada C. Management of Latin American River Basins: Amazon, Plata, and São Francisco. United Nations University Press; 1999.

[114] de CD Melo D, Scanlon BR, Zhang Z, Wendland E, Yin L. Reservoir storage and hydrologic responses to droughts in the Paraná River basin, south-eastern Brazil. Hydrology \& Earth System Sciences. 2016;20(11). doi:10.5194/hess-20-4673-2016.

[115] Erfanian A, Wang G, Fomenko L. Unprecedented drought over tropical South America in 2016: significantly under-predicted by tropical SST. Scientific reports. 2017;7(1):5811. doi:10.1038/s41598-01705373-2.

[116] Azevedo SCd, Cardim GP, Puga F, Singh RP, Silva EAd. Analysis of the 2012-2016 drought in the northeast Brazil and its impacts on the Sobradinho water reservoir. Remote Sensing Letters. 2018;9(5):438-446. doi:10.1080/2150704X.2018.1437290.

[117] Dobrovolski R, Rattis L. Water collapse in Brazil: the danger of relying on what you neglect. Natureza \& Conservação. 2015;1(13):8083. doi:10.1016/j.ncon.2015.03.006.

[118] Ioris AA. The troubled waters of Brazil: Nature commodification and social exclusion. Capitalism Nature Socialism. 2007;18(1):28-50. doi:10.1080/10455750601164618.

[119] Victor DG, Almeida P, Wong L. Water Management Policy in Brazil. 
SSRN Electronic Journal. 2015;doi:10.2139/ssrn.2670847.

[120] Spring J. Brazil battles drought as world's largest water forum meets. Reuters; 2018. Available from: https://www.reuters.com/article/usbrazil-water-forum/brazil-battles-drought-as-worlds-largest-waterforum-meets-idUSKBN1GY1SI.

[121] Alvala R, Cunha AP, Brito SS, Seluchi ME, Marengo JA, Moraes OLL, et al. Drought monitoring in the Brazilian Semiarid region. Anais da Academia Brasileira de Ciências. 2017;91(suppl 1). doi:10.1590/0001-3765201720170209.

[122] Nobre A. The future climate of Amazonia: Scientific assessment report. WWF; 2014. Available from: http://wwf.panda.org/?232041/ The-Future-Climate-of-Amazonia.

[123] Gerberg J. Megacity without water: São Paulo's drought. Time. 2015; Available from: http://time.com/4054262/drought-brazilvideo/.

[124] T M. Drought Hurts Brazil's Economy, Helps Commodities. Wall Street Daily. 2015; Available from: http://www.wallstreetdaily.com/ 2015/02/19/brazil-drought-economy-commodities/.

[125] Watts J. Brazil's worst drought in history prompts protests and blackouts. The Guardian. 2015; Available from: http://www.theguardian. com/world/2015/jan/23/brazil-worst-drought-history.

[126] Ross P. São Paulo Drought 2015: Photos Of Historic Water Crisis In Brazil Show City On The Brink Of Collapse. International Business Times. 2015; Available from: http://www.ibtimes.com/sao-paulo-drought-2015-photoshistoric-water-crisis-brazil-show-city-brink-collapse-1912767.

[127] Boico VF, Wendland E, Batista JAdN. Assessment of the potentiometric drawdown in the Guarani Aquifer System in Bauru/SP by a model of analytical elements. Brazilian Journal of Water Resources. 2018;23. doi:10.1590/2318-0331.0318170121.

[128] Magalhaes L, Johnson R, Kiernan P. Blackouts Roll Through Large Swath of Brazil. Wall Street Journal. 2015; Available from: https://www.wsj.com/articles/blackouts-roll-through-largeswath-of-brazil-1421709716.

[129] Jelmayer R. Chao L. Drought-stricken São Paulo battles dengue fever outbreak. The Wall Street Journal. 2015; Available from: https://www.wsj.com/articles/drought-stricken-sao-paulobattles-dengue-fever-outbreak-1425420508.

[130] Sun T, Ferreira VG, He X, Andam-Akorful SA. Water availability of São Francisco river basin based on a space-borne geodetic sensor. Water. 2016;8(5):213. doi:10.3390/w8050213.

[131] Ward M. Worries grow as serious drought hits São Paulo, Brazil; 2015. Available from: https://www.cnbc.com/2015/06/30/worriesgrow-as-serious-drought-hits-sao-paulo-brazil.html.

[132] Lewis J. Drought Drives Up Brazil's Supermarket Produce Prices. Wall Street Journal. 2015 Feb 6; Available from: https://www.wsj.com/articles/drought-drives-up-brazilssupermarket-produce-prices-1423245993.

[133] São Francisco River Basin. CEMIG; 2012. Available from: http://www.cemig.com.br/en-us/Company_and_Future/ Sustainability/Programs/environmental_programs/peixe_vivo/ river_basins/Pages/Sao_Francisco_River_Basin.aspx.

[134] Cirilo JA. Public water resources policy for the semi-arid region. Estudos Avançados. 2008;22(63):61-82. doi:10.1590/S010340142008000200005

[135] Góes P. With Its Headwaters Dry, Brazilians Fear the Death of the 'Old Frank' River. Global Voices. 2014; Available from: https://globalvoices.org/2014/11/08/with-its-headwaters-drybrazilians-fear-the-death-of-the-old-frank-river/.

[136] Jelmayer R. Brazil to limit water abstractions from São Francisco river. BN Americas. 2017 July 6; Available from: https://www.bnamericas.com/en/news/waterandwaste/brazilto-limit-water-abstractions-from-sao-francisco-river.

[137] Jelmayer R. São Francisco river water diversion threatens supply of Campina Grande. BN Americas. 2017 Aug 8; Available from: https://www.bnamericas.com/en/news/sao-francisco-riverwater-diversion-threatens-supply-of-campina-grande.

[138] Roland F, Huszar V, Farjalla V, Enrich-Prast A, Amado A, Ometto J. Climate change in Brazil: perspective on the biogeochemistry of inland waters. Brazilian Journal of Biology. 2012;72(3):709-722. doi:10.1590/S1519-69842012000400009.

[139] Wilkinson J, Reydon B, Di Sabbato A. Concentration and for- eign ownership of land in Brazil in the context of global land grabbing. Canadian Journal of Development Studies/Revue canadienne d'études du développement. 2012;33(4):417-438. doi:10.1080/02255189.2012.746651.

[140] Dehlinger K. South America Calling: Brazil ports ready for soybean boom. The Progressive Farmer. 2018; Available from: https://www. dtnpf.com/agriculture/web/ag/perspectives/blogs/south-americacalling/blog-post/2018/05/24/brazil-ports-ready-soybean-boom.

[141] Tomson B. As infrastructure improves, Brazil increases soy exports to China. Agripulse. 2018; Available from: https://www.agripulse.com/articles/10463-brazils-improving-infrastructure-allowsit-to-grab-more-and-more-of-chinas-soybean-market.

[142] Kraham SJ. Environmental impacts of industrial livestock production. In: International Farm Animal, Wildlife and Food Safety Law. Springer; 2017. pp. 3-40. doi:10.1007/978-3-319-18002-1_1.

[143] McElroy A, Townsend P. Medical anthropology in ecological perspective. Westview Press; 2015

[144] Posicionamento Do Instituto Nacional De Cancer José Alencar Gomes Da Silva Acerca Dos Agrotóxicos. INCA; 2011. Available from: http://www1.inca.gov.br/inca/Arquivos/comunicacao/ posicionamento_do_inca_sobre_os_agrotoxicos_06_abr_15.pdf.

[145] Why Genetically Modified Crops Pose A Threat to Peasants, Food Sovereignty, Health, and Biodiversity on the Planet Introduction. ETC Group; 2013. Available from: http://www.cibosostenibile.it/ appelloogmingle.pdf.

[146] Rigotto RM, Vasconcelos DP, Rocha MM. Pesticide use in Brazil and problems for public health. Cadernos de Saude Publica 2014:30:1360-1362. doi:10.1590/0102-311XPE020714.

[147] Prada P. Fateful harvest, Why Brazil has a big appetite for risky pesticides. Reuters, Special Report. 2015; Available from: https: //www.reuters.com/investigates/special-report/brazil-pesticides/.

[148] Carneiro FF, et al. Dossiê ABRASCO: um alerta sobre os impactos dos agrotóxicos na saúde. EPSJV/Expressão Popular. 2015; Available from: https://www.abrasco.org.br/dossieagrotoxicos/wpcontent/uploads/2013/10/DossieAbrasco_2015_web.pdf.

[149] Almeida VESd, Friedrich K, Tygel AF, Melgarejo L, Carneiro FF. Use of genetically modified crops and pesticides in Brazil: growing hazards. Ciencia \& Saude Coletiva. 2017;22:3333-3339. doi:10.1590/1413-812320172210.17112017

[150] In 1989, Brazil established one of the toughest pesticide laws $(7,802 / 1989)$ in the world (at the time), however severe budgetary and staffing limitations hindered implementation and enforcement.

[151] Pignati WA, de Souza e Lima FAN, de Lara SS, Correa MLM, Barbosa JR, da Costa Leão LH, et al. Distribuição espacial do uso de agrotóxicos no Brasil: uma ferramenta para a Vigilância em Saúde. Ciência \& Saúde Coletiva. 2017;22(10):3281-3293. doi:10.1590/1413-812320172210.17742017

[152] Menten JO. SAFRA 2008-2009: Tendencias e desafiosDefensivos agricolas; 2008

[153] Carneiro FF, et al. Dossiê ABRASCO: um alerta sobre os impactos dos agrotóxicos na saúde. EPSJV/Expressão Popular. 2015; Available from: https://www.arca.fiocruz.br/bitstream/icict/26221/2/ LivroEPSJV013036.pdf.

[154] Barbosa A, Solano MdL, Umbuzeiro GdA. Pesticides in drinking water-the Brazilian monitoring program. Frontiers in Public Health. 2015;3:246. doi:10.3389/fpubh.2015.00246.

[155] Nogueira EN, Dores EF, Pinto AA, Amorim RS, Ribeiro ML, Lourencetti C. Currently used pesticides in water matrices in Central-Western Brazil. Journal of the Brazilian Chemical Society. 2012;23(8):1476-1487. doi:10.1590/S0103-50532012005000008.

[156] Dores EF, Carbo L, Ribeiro ML, De-Lamonica-Freire EM. Pesticide levels in ground and surface waters of Primavera do Leste Region, Mato Grosso, Brazil. Journal of Chromatographic Science. 2008;46(7):585-590. doi:10.1093/chromsci/46.7.585.

[157] Wendland E, Rabelo J, Roehrig J. Guarani Aquifer System-The Strategical Water Source In South America. Köln, Germany: Institut für Tropentechnologie; 2006. Available from: https: //www.researchgate.net/publication/240617726_Guarani_Aquifer_ System_-_The_Strategical_Water_Source_In_South_America.

[158] Pignati WA, Lima FANdS, Lara SSd, Correa MLM, Barbosa JR, Leão LHdC, et al. Distribuição espacial do uso de agrotóxicos no Brasil: uma ferramenta para a Vigilância em Saúde. Cien- 
cia \& Saude Coletiva. 2017;22:3281-3293. doi:10.1590/1413812320172210.17742017.

[159] Altieri M. Agroecologia: bases científicas para uma agricultura sustentável. Expressão Popular/AS-PTA; 2012.

[160] You Don't Want to Breathe Poison Anymore: The Failing Response to Pesticide Drift in Brazil's Rural Communities. Human Rights Watch. 2018; Available from: https://www.hrw.org/sites/default/files/ report_pdf/brazil0718_web.pdf.

[161] Bøhn T, Cuhra M, Traavik T, Sanden M, Fagan J, Primicerio R. Compositional differences in soybeans on the market: glyphosate accumulates in Roundup Ready GM soybeans. Food Chemistry. 2014;153:207-215. doi:10.1016/j.foodchem.2013.12.054.

[162] Bøhn T, Cuhra M. How "Extreme Levels" of Roundup in food became the industry norm. Independent Science News. 2014;24:2014.

[163] Porto MFdS. The tragic "Poison Package": lessons for Brazilian society and Public Health. Cadernos de Saude Publica. 2018;34(7). doi:10.1590/0102-311x00110118.

[164] Boldrini A. Entenda o projeto de lei que altera registro de agrotóxicos. Folha de São Paulo. 2018; Available from: https://www1.folha.uol.com.br/mercado/2018/05/entenda-oprojeto-de-lei-que-altera-registro-de-agrotoxicos.shtml.

[165] Nascimento N. Governo desconhece papel estratégico do Consea, avalia presidente do Conselho. Agrotóxico Mata. 2019 Jan 10; Available from: http://contraosagrotoxicos.org/governo-desconhecepapel-estrategico-do-consea-avalia-presidente-do-conselho/.

[166] Carson R. Silent spring. Houghton Mifflin Harcourt; 2002.

[167] Watts MJ. Violent Geographies. speaking the unspeakable and the politics of space. City \& Society. 2001;13(1):85-117. doi:10.1525/city.2001.13.1.85.

[168] Magdoff $F$. Twenty-first-century land grabs: Accumulation by agricultural dispossession. Monthly Review. 2013;65(6):1. Available from: https://monthlyreview.org/2013/11/01/twenty-first-centuryland-grabs/.

[169] Coe MT, Brando PM, Deegan LA, Macedo MN, Neill C, Silverio DV. The forests of the Amazon and Cerrado moderate regional climate and are the key to the future. Tropical Conservation Science. 2017:10:1940082917720671. doi:10.1177/1940082917720671.

[170] Lathuillière MJ, Johnson MS, Donner SD. Water use by terrestrial ecosystems: temporal variability in rainforest and agricultural contributions to evapotranspiration in Mato Grosso, Brazil. Environmental Research Letters. 2012;7(2):024024. doi:10.1088/17489326/7/2/024024.

[171] Panday PK, Coe MT, Macedo MN, Lefebvre P, de Almeida Castanho AD. Deforestation offsets water balance changes due to climate variability in the Xingu River in eastern Amazonia. Journal of Hydrology. 2015;523:822-829. doi:10.1016/j.jhydrol.2015.02.018.

[172] Silvério DV, Brando PM, Macedo MN, Beck PS, Bustamante M, Coe MT. Agricultural expansion dominates climate changes in southeastern Amazonia: the overlooked non-GHG forcing. Environmental Research Letters. 2015;10(10):104015. doi:10.1088/17489326/10/10/104015

[173] Pinto HS, Assad ED. Aquecimento global e cenários futuros da agricultura brasileira. Campinas, SP, Brazil: Embrapa; 2008. Available from: https://secured-static.greenpeace.org/brasil/PageFiles/ 3580/Eduardo_Assadi_EMBRAPA.pdf.

[174] Figueiredo PN. New challenges for public research organisations in agricultural innovation in developing economies: Evidence from Embrapa in Brazil's soybean industry. The Quarterly Review of Economics and Finance. 2016;62:21-32. doi:10.1016/j.qref.2016.07.011.

[175] Climate Change 2014: Synthesis Report. Contribution of Working Groups I, II and III to the Fifth Assessment Report of the Intergovernmental Panel on Climate Change. Geneva, Switzerland: IPCC; 2014. Available from: https://www.ipcc.ch/report/ar5/syr/.

[176] Martinelli LA, Batistella M, Silva RFBd, Moran E. Soy Expansion and Socioeconomic Development in Municipalities of Brazil. Land. 2017;6(3):62. doi:10.3390/land6030062.

[177] Weinhold D, Killick E, Reis EJ. Soybeans, poverty and inequality in the Brazilian Amazon. World Development. 2013;52:132-143. doi:10.1016/j.worlddev.2012.11.016.

[178] Agricultural Policy Monitoring and Evaluation. Paris, France: Trade and Agriculture Directorate, Committee for Agriculture, Organisation for Economic Co-operation and Development; 2017. Available from: https://www.oecd-ilibrary.org/agriculture-and-food/agriculturalpolicy-monitoring-and-evaluation-2018_agr_pol-2018-en.

[179] Santana CAM, Nascimento JR. Public Policies and Agricultural Investment in Brazil. Rome. Italy: FAO; 2012 Available from: http://www.fao.org/fileadmin/templates/tci/pdf/ InvestmentPolicy/Inv_in_Br_agriculture_-_20_08_2012.pdf.

[180] Scoones I, Edelman M, Borras Jr SM, Hall R, Wolford W, White B. Emancipatory rural politics: confronting authoritarian populism. The Journal of Peasant Studies. 2018;45(1):1-20. doi:10.1080/03066150.2017.1339693.

[181] Fitz D. Evaluating the impact of market-assisted land reform in Brazil. World Development. 2018;103:255-267. doi:10.1016/..worlddev.2017.10.007.

[182] Sauer S, Balestro MV, Schneider S. The ambiguous stance of Brazil as a regional power: piloting a course between commodity-based surpluses and national development. Globalizations. 2018;15(1):3255. doi:10.1080/14747731.2017.1400232.

[183] Sauer S, Mészáros G. The political economy of land struggle in Brazil under Workers' Party governments. Journal of Agrarian Change. 2017:17(2):397-414. doi:10.1111/joac.12206.

[184] Vieira Filho JER. Technological clusters in Brazilian agriculture: production and challenges. Brasília, Brazil: Instituto de Pesquisa Econômica Aplicada (Ipea); 2017. Available from: http://www.ipea.gov.br/portal/index.php?option=com_content\& view $=$ article\&id $=30602$

[185] Svampa M. Contesting Neo-Extractive Accumulation in Latin America. Global Dialogue, International Sociological Association; 2016.

[186] Sauer S, Pereira Leite S. Agrarian structure, foreign investment in land, and land prices in Brazil. The Journal of Peasant Studies. 2012;39(3-4):873-898. doi:10.1080/03066150.2012.686492.

[187] Alberto FC, Paulon GE, Mancano FB. Banco de Dados da Luta pela Terra Relatório Brasil 2011; 2011. Available from: http: //docs.fct.unesp.br/nera/projetos/dataluta_brasil_2011.pdf.

[188] Gonzales J. Soy King Blairo Maggi wields power over Amazon's fate, say critics. Mongabay; 2018. Available from: https://news.mongabay.com/2017/07/soy-king-blairo-maggiwields-power-over-amazons-fate-say-critics/.

[189] Leahy J. Temer Accused of Backtracking on Rainforest Veto to Gain Votes. Folha de São Paulo. 2017 Jul 24; Available from: https://www1.folha.uol.com.br/internacional/en/brazil/2017/07/ 1903799-temer-accused-of-backtracking-on-rainforest-veto-togain-votes.shtml.

[190] Gonzales J. Brazil agribusiness company accuses ally Temer in secret bribe taping. Mongabay. 2017 May 23.

[191] Michel Temer (executive order). MP 759/2016; 2016. Available from: http://www.camara.gov.br/proposicoesWeb/fichadetramitacao? idProposicao=2122078.

[192] Bedeschi L, Romeiro P. Brazil's New Land Regularization Law: A Territorial Attack on Several Fronts. Rio On Watch. 2017 Mar 13.

[193] Fearnside P. Business as usual: a resurgence of deforestation in the Brazilian Amazon. Yale Environ. 2017;360. Available from: https://e360.yale.edu/features/business-as-usual-aresurgence-of-deforestation-in-the-brazilian-amazon.

[194] Fearnside PM. Brazilian politics threaten environmental policies. Science. 2016;353(6301):746-748. doi:10.1126/science.aag0254.

[195] Fearnside PM, de Alencastro Graça PML. BR-319: Brazil's ManausPorto Velho Highway and the potential impact of linking the arc of deforestation to central Amazonia. Environmental Management. 2006;38(5):705-716. doi:10.1007/s00267-005-0295-y.

[196] Branford S, Torres M. Brazil's high court curbs executive power to dismember protected areas. Mongabay. 2018; Available from: https://news.mongabay.com/2018/04/brazils-high-courtcurbs-executive-power-to-dismember-protected-areas/.

[197] Costa SHG. A questão agrária no Brasil e a bancada ruralista no Congresso Nacional. Universidade de São Paulo; 2012. Available from: http://www.teses.usp.br/teses/disponiveis/8/8136/ tde-08012013-143125/pt-br.php. 10.11606/D.8.2012.tde-08012013143125.

[198] Boadle A. Brazil farm lobby seeks to dismantle indigenous affairs agency. Reuters. 2017 May 16;Https://www.reuters.com/article/usbrazil-indigenouspeople/brazil-farm-lobby-seeks-to- 
dismantle-indigenous-affairs-agency-idUSKCN18C2UM

https://www.reuters.com/article/us-brazil-indigenouspeople/brazilfarm-lobby-seeks-to-dismantle-indigenous-affairs-agencyidUSKCN18C2UM.

[199] Poirier C. Institution Protecting Indigenous Rights in Brazil Under Attack. Amazon Watch. 2018 Aug 3;Https://amazonwatch.org/news/2018/0403-institutionprotecting-indigenous-rights-in-brazil-under-attack. https://amazonwatch.org/news/2018/0403-institution-protectingindigenous-rights-in-brazil-under-attack.

[200] Branford S, Torres M. Brazil's political storm driving Amazon deforestation higher. Mongabay. 2018 Jul $\quad 9 ;$ Https://news.mongabay.com/2018/07/brazilspolitical-storm-driving-amazon-deforestation-higher/. https://news.mongabay.com/2018/07/brazils-political-stormdriving-amazon-deforestation-higher/.

[201] Brazil: Rainforest pays the price for the country's crisis. Financial Times. 2018; Available from: https://www.ft.com/content/971f03aaf9e0-11e7-9b32-d7d59aace167.

[202] Branford S, Torres M. How Brazil's Temer Administration Is Provoking Violence Against Agrarian Reform. Pacific Standard. 2017; Available from: https://psmag.com/social-justice/temer-administration-isprovoking-violence-against-agrarian-reform.

[203] Andrade F. Veja as frases mais polemicas dos candidatos neste 20 turno. Destak. 2018; Available from: https://www.destakjornal.com. $\mathrm{br} / \mathrm{brasil} /$ eleicoes-2018/detalhe/veja-as-frases-mais-polemicasdos-candidatos-neste-2-turno?ref=Brasil_Ultimas.

[204] Moraes R. "Esses marginais vermelhos serão banidos de nossa pátria", diz Bolsonaro. Reuters. 2018 Oct 21;Https://br.reuters.com/article/topNews/idBRKCN1MW017OBRTP. https://br.reuters.com/article/topNews/idBRKCN1MW017OBRTP.

[205] Bolsonaro fala ao Brasil. Estamos no segundo turno!; 2018. Youtube via Entrevista / The Noite. São Paulo, Brasil: Jair Bolsonaro; Available from: https://youtu.be/W03TbRU7So0.

[206] Charleaux JP. O que é ativismo. E por que é um perigo 'acabar' com ele. Nexo. 2018 Oct 13

[207] Dolzan M. Não podemos abrir as portas para todo mundo, diz Bolsonaro em palestra na Hebraica. Estadão Política, São Paulo. 2017 Apr 13;3. Https://politica.estadao.com.br/noticias/geral,naopodemos-abrir-as-portas-para-todo-mundo-dizbolsonaro-em-palestra-na-hebraica, 70001725522 . https://politica.estadao.com.br/noticias/geral,nao-podemosabrir-as-portas-para-todo-mundo-diz-bolsonaro-em-palestra-nahebraica,70001725522.

[208] Fenizola L. O Que Esperar da Política Brasileira em 2018? Parte 8: A Favela nos Planos dos Presidenciáveis. Rio de Janeiro: Rio On Watch. 2018; Available from: http://rioonwatch.org.br/?p=36586

[209] Inocêncio ME. O PROCEDER e as tramas do poder na territorialização do capital no Cerrado. Universidade Federal de Goiás; 2010. Available from: https://repositorio.bc.ufg.br/tede/ handle/tde/2736.

[210] Clements EA, Fernandes BM. Land grabbing, agribusiness and the peasantry in Brazil and Mozambique. Agrarian South: Journal of Political Economy. 2013;2(1):41-69. doi:10.1177/2277976013477185.

[211] Making a killing from hunger. Against the grain GRAIN. 2008; Available from: https://www.grain.org/article/entries/178-making-akilling-from-hunger.

[212] Seized: The 2008 land grab for food and financial security. Against the grain GRAIN. 2008; Available from: https://www.grain.org/article/entries/93-seized-the-2008-landgrabfor-food-and-financial-security.

[213] Flexor G, Leite SP. Land market and land grabbing in Brazil during the commodity boom of the 2000s. Contexto Internacional. 2017;39(2):393-420. doi:10.1590/s0102-8529.2017390200010.

[214] Butler R. What happens when the soy and palm oil boom ends? Mongabay. 2017 Feb 21; Available from: https://news.mongabay.com/2017/02/what-happens-whenthe-soy-and-palm-oil-boom-ends/.

[215] Spanne A. Hunger for Meat Plows Up Brazil's Cerrado Plains. Scientific American. 2014; Available from: https://www.scientificamerican. com/article/hunger-for-meat-plows-up-brazils-cerrado-plains/.
[216] Brown-Lima C, Cooney M, Cleary D. An overview of the BrazilChina soybean trade and its strategic implications for conservation. Washington, DC, USA: The Nature Conservancy; 2010. Available from: https://www.fcrn.org.uk/sites/default/files/brazil-chinasoybean-trade.pdf.

[217] Gu H, Thukral N. Soy source: Brazil's share of soybean exports to China hits record. Reuters. 2018; Available from: https://www.reuters.com/article/us-china-economy-tradesoybeans/soy-source-brazils-share-of-soybean-exports-to-chinahits-record-idUSKBN1FE111.

[218] Why China Is Hungry For Brazilian Soy. Forbes. 2018; Available from: https://www.forbes.com/sites/stratfor/2018/04/10/why-chinais-hungry-for-brazilian-soy/\#19b223b8321d.

[219] Amaral D. Brazil's Soy Infrastructure: Improvements and Perspectives USDA's 94th Annual Agricultural Outlook Forum; 2018. Available from: https://www.usda.gov/oce/forum/2018/speeches/ Daniel_Amaral.pdf.

[220] Kuijpers K. Dutch support soy transport mega-project, posing major risk to Amazon. Investico; 2018. Available from: https://www.platform-investico.nl/artikel/dutch-support-soytransport-mega-project-posing-major-risk-amazon/.

[221] Harnessing the power of global supply chains to halt deforestation driven by soy. A briefing for policymakers and the private sector; 2018. Available from: http: //b8f65cb373b1b7b15feb-c70d8ead6ced550b4d987d7c03fcdd1d. r81.cf3.rackcdn.com/cms/reports/documents/000/003/112/ original/SDG_Policy_Brief_Cerrado.pdf?1520866975.

[222] Richards PD, Walker RT, Arima EY. Spatially complex land change: The Indirect effect of Brazil's agricultural sector on land use in Amazonia. Global Environmental Change. 2014;29:1-9. doi:10.1016/j.gloenvcha.2014.06.011.

[223] The fifteen municipalities responsible (of the 337 municipalities that make up the region) are: Alto Parnaíba, Baixa Grande do Ribeiro, Balsas, Barreiras, Jaborandi, Bom Jesus, Gilbués, Tasso Fragoso, Correntina, Currais, Formosa do Rio Preto, Ribeiro Goncalves, Santa Filomena, Saão Desidério, Urucuí. Twelve of these municipalities have been identified as priority areas for monitoring and combating illegal deforestation in the Cerrado..

[224] da República P. LEI No 12.787, DE 11 DE JANEIRO DE 2013; 2013

[225] Brazil: Framework Analysis for Public-Private Partnerships in Irrigation. Public-Private Infrastructure Advisory Facility; 2009 Available from: http://documents.worldbank.org/curated/en/ 807811522213372763/pdf/124668-WP-PUBLIC-Brazil-IrrigationPPP-April-2009.pdf.

[226] Lima J, Silva E, Oliveira-Filho EC, Martins E, Reatto A, Bufon VB. The relevance of the Cerrado's water resources to the Brazilian development. In: Proceedings of the XIVth IWRA World Water Congress. IWRA, Montpellier; 2011. Available from: https: //www.iwra.org/member/congress/resource/PAP00-5872.pdf.

[227] Brazil: Latest Agriculture Frontier in Western Bahia and MATOPIBA. United States Department of Agriculture; 2012. Available from: https://ipad.fas.usda.gov/highlights/2012/07/Brazil_MATOPIBA/.

[228] Brazil Systematic Country Diagnostic: Retaking the Path to Inclusion, Growth and Sustainability. Washington, DC, USA: Wold Bank Group; 2016. Available from: http://documents.worldbank.org/ curated/en/180351467995438283/pdf/101431-REVISED-SCDBrazil-SCD-Final-version-May-6-2016.pdf.

[229] Lathuillière M. To Irrigate Or Not To Irrigate? Implications For Agricultural Intensification In Southern Amazonia. Science Trends. 2018 May;doi:10.31988/scitrends.17255.

[230] Mano A. Brazil's Mato Grosso leads push for GM-free soy. Reuters. 2017; Available from: https://www.reuters.com/article/brazilgrains-gmo/brazils-mato-grosso-leads-push-for-gm-free-soyidUSL1N1IAOKW.

[231] Lathuillière MJ, Dalmagro HJ, Black TA, de Arruda PH, Hawthorne I Couto EG, et al. Rain-fed and irrigated cropland-atmosphere water fluxes and their implications for agricultural production in Southern Amazonia. Agricultural and Forest Meteorology. 2018;256:407-419. doi:10.1016/j.agrformet.2018.03.023.

[232] Phelps J, Carrasco LR, Webb EL, Koh LP, Pascual U. Agricultural intensification escalates future conservation costs. Proceedings 
of the National Academy of Sciences. 2013;110(19):7601-7606. doi:10.1073/pnas.1220070110.

[233] Pretty J, Bharucha ZP. Sustainable intensification in agricultural systems. Annals of Botany. 2014;114(8):1571-1596. doi:10.1093/aob/mcu205.

[234] Boerema A, Peeters A, Swolfs S, Vandevenne F, Jacobs S, Staes $\mathrm{J}$, et al. Soybean trade: balancing environmental and socio-economic impacts of an intercontinental market. PloS one. 2016;11(5):e0155222. doi:10.1371/journal.pone.0155222.

[235] Appelgren B. Water Ethics. s 5. Unesco; 2004.

[236] Fahlquist JN. Moral responsibility for environmental problems-Individual or institutional? Journal of Agricultural and Environmental Ethics. 2009;22(2):109-124. doi:10.1007/s10806-0089134-5.

[237] Gardiner SM. Ethics and global climate change. Ethics. 2004:114(3):555-600. doi:10.1086/382247.

[238] Peterson M. The EU-US Dispute Over Regulation of Genetically Modified Organisms, Plants, Feeds, and Foods-Case Summary. International Dimensions of Ethics Education in Science and Engineering Case Study Series. 2009; Available from: https://scholarworks.umass.edu/cgi/viewcontent.cgi?article= 1007\&context=edethicsinscience.

[239] Ackermann F. Critique of Cost-Benefit Analysis, and Alternative Approaches to Decision-Making. A report for Friends of the Earth England, Wales and Northern Ireland; 2008. Available from: https://friendsoftheearth.uk/sites/default/files/downloads/ policy_appraisal.pdf.

[240] Leopold A. The Land Ethic. In: A Sand County Almanac and sketches here and there. 1st ed. Oxford University Press; 1949.

[241] Nachmany M, Fankhauser S, Setzer J, Averchenkova A. Global trends in climate change legislation and litigation: 2017 update. Grantham Research Institute on Climate Change and the Environment; 2017. Available from: http://www.lse.ac.uk/Granthamlnstitute/publication/global-trendsin-climate-change-legislation-and-litigation-2017-update/.

[242] International Comparative Legal Guides. Germany: Environment \& Climate Change Law 2019, ICLG website. Available from: https://iclg.com/practice-areas/environment-and-climatechange-laws-and-regulations/germany.

[243] Wang U. German lawsuit takes aim at climate impacts of agriculture. Climate Liability News; 2018. Available from: https://www.climateliabilitynews.org/2018/08/08/agriculturegermany-nitrates-methane-climate/.

[244] Darko J. Report: Nitrate threatens groundwater in Germany. Available from: https://p.dw.com/p/2VBY0.

[245] Steinfeld H, Gerber P, Wassenaar T, Castel V, Rosales M, De Haan C, et al. Livestock's long shadow. Rome, Italy: FAO; 2006. Available from: http://www.fao.org/docrep/010/a0701e/a0701e00.HTM.

[246] Conversely, in a third of cases globally, corporate law suits challenge unfavorable rulings that have gone against granting a license (for example, for water extraction) on the basis of climate change or climate variability.

[247] McCormick S, Glicksman RL, Simmens SJ, Paddock L, Kim D, Whited B. Strategies in and outcomes of climate change litigation in the United States. Nature Climate Change. 2018;8(9):829. doi:10.1038/s41558-018-0240-8.

[248] An analysis of US climate change cases for the 25-year period to 2016 (873 lawsuits) found that the most common suits were brought against coal-fired power plant emissions and air quality concerns. Most suits were lost by litigants asking the court to impose more regulations to curb emissions, as courts were swayed by industry arguments that increasing regulations would negatively affect the economic bottom line.

[249] Effective strategies involved citing climate science and other types of data, and lodging suits through collaboration to form a coalition of plaintiffs, especially in states (or by individuals) that have been harmed by some aspect of climate change.

[250] A Blueprint for Climate Action in Agriculture. Global Harvest Initiative; 2016. Available from: https://www.globalharvestinitiative.org/ GAP/ABlueprintforClimateActioninAgriculture.pdf.

[251] Dewey S, Hanson L, Horan C, Jacobs W, Goho S. Opportunities to Address Climate Change in the Farm Bill. 2017; Available from: http://environment.law.harvard.edu/emmett-clinic/.

[252] Cerri CC, Bernoux M, Maia SMF, Cerri CEP, Costa Junior C Feigl BJ, et al. Greenhouse gas mitigation options in Brazil for land-use change, livestock and agriculture. Scientia Agricola. 2010;67(1):102-116. doi:10.1590/S0103-90162010000100015.

[253] Brazil: Country Note on Climate Change Aspects in Agriculture. World Bank; 2007. Available from: http://siteresources.worldbank. org/INTLAC/Resources/Climate_BrazilWeb.pdf.

[254] Campbell B, Mann W, Meléndez-Ortiz R, Streck C, Tennigkeit T, Vermeulen S. Agriculture and Climate Change Policy Brief: Main Issues for the UNFCCC and Beyond. 2011; Available from: https: //ccafs.cgiar.org/publications/agriculture-and-climate-changepolicy-brief-main-issues-unfccc-and-beyond\#.XKN_li2ZOu4.

[255] IUCN Programme 2017-2020; 2016. Available from: https://portals. iucn.org/library/sites/library/files/documents/WCC-6th-001.pdf.

[256] Cano Pecharroman L. Rights of nature: Rivers that can stand in court. Resources. 2018;7(1):13. doi:10.3390/resources7010013.

[257] Mexico City Political Constitution. Public Administration of Mexico City Mexico; 2017. Available from: https://www.cdmx.gob.mx/storage/app/uploads/public/59a/588/ 5d9/59a5885d9b2c7133832865.pdf.

[258] First Debate on the National Senate on the Rights of Nature. Argentine Senate; 2015. Available from: http://www.senado.gov.ar/ prensa/13264/noticias.

[259] Ito M, ECI. European Citizens Initiative for the Rights of Nature (Working Draft); 2017. Available from: https://natures-rights.org/ECIDraftDirective-Draft.pdf.

[260] Gordon G. Environmental Personhood. Columbia J Environ Law; 2018. Available from: http://www.columbiaenvironmentallaw.org/ environmental-personhood/.

[261] Branford S. Brazil high court Forest Code ruling largely bad for environment, Amazon: NGOs; 2018. Available from: https://news.mongabay.com/2018/03/brazil-high-court-forestcode-ruling-largely-bad-for-environment-amazon-ngos/.

[262] IPAM. MapBiomas mapeia três décadas de mudanças na ocupação territorial do país; 2018. Available from: http://ipam.org.br/projeto-mapbiomas-mapeia-tres-decadasde-mudancas-na-ocupacao-territorial-do-brasil/.

[263] Soares-Filho B, Rajão R, Macedo M, Carneiro A, Costa W, Coe M, et al. Cracking Brazil's forest code. Science. 2014;344(6182):363364. doi:10.1126/science.1246663.

[264] Coplan KS. Public Trust Limits on Greenhouse Gas Trading Schemes: A Sustainable Middle Ground?"(2010). Colum J Envtl L;35. Available from: https://digitalcommons.pace.edu/lawfaculty/ 597

[265] Wood MC. Advancing the sovereign trust of government to safeguard the environment for present and future generations (Part 1): ecological realism and the need for a paradigm shift. Envtl $L$. 2009;39:43. Available from: https://papers.ssrn.com/sol3/papers. $\mathrm{cfm}$ ?abstract_id $=1988524$.

[266] Washburn E, Núñez A. Is the Public Trust a Viable Mechanism to Regulate Climate Change. Nat Resources \& Env't. 2012;27:23. Available from: https: //www.americanbar.org/groups/environment_energy_resources/ publications/natural_resources_environment/2012_13/fall_2012/ is_public_trust_viable_mechanism_regulate_climate_change/?q= \&fq $=(\mathrm{id} \% 3 \mathrm{~A} \% 5 \mathrm{C} \% 2$ Fcontent $\% 2$ Faba-cms-dotorg\%2Fen $\%$ 2Fgroups\%2Fenvironment_e.

[267] Blumm MC, Guthrie RD. Internationalizing the public trust doctrine Natural law and constitutional and statutory approaches to fulfilling the Saxion Vision. UCDL Rev. 2011;45:741. Available from: https://papers.ssrn.com/sol3/papers.cfm?abstract_id $=1816628$.

[268] Boswell A. Strengthening the Precautionary Principle in the Post-Paris Climate Regime. Environment: Science and Policy for Sustainable Development. 2017;59(5):26-37. doi:10.1080/00139157.2017.1350007.

[269] Van Der Sluijs J, Turkenburg W. Climate change and the Precautionary Principle. In: Elizabeth Fisher JJ, René von Schomberg, editors. Implementing The Precautionary Principle: Perspectives and Prospects; 2006. Available from: http://www.nusap.net/downloads/ Climate_Change_and_the_Precautionary_Principle.pdf.

[270] Principles of EU Environmental Law: The Preventative and Precau- 
tionary Principle. Euopean Commission; 2012.

[271] Cabral L, Shankland A, Locke A, Duran J. Mozambique's Agriculture and Brazil's Cerrado «Model»: Miracle or Mirage. GREAT insights. 2012;1(10). Available from: https://ecdpm.org/great-insights/africa-turning-point-mozambiquecase/mozambiques-agriculture-brazils-cerrado-model/.

[272] Wise T. What happened to the biggest land grab in Africa? Searching for ProSAVANA in Mozambique. Food Thank. 2014;20:12. Available from: https://foodtank.com/news/2014/12/what-happened-tothe-biggest-land-grab-in-africa-searching-for-prosavana-in/.

[273] Thus far, Mozambique's ProSavana conversion has been unsuccessful. The soil of the Cerrado and the Nacala Corridor dramatically differ from one another, foreign ownership of land is prohibited, much of the Corridor is already occupied, Mozambique legally protects the use rights of farmers who have been productive on the land for at least ten years, and there is a lack of road infrastructure to enable transportation of product to port. Though the project remains on the table, it seems that including the participation of small farmers in ProSavana is essential to it moving forward. This would require a dramatic change in the project's development model, which at the moment seems unlikely.

[274] Köhler HR, Triebskorn R. Wildlife ecotoxicology of pesticides: can we track effects to the population level and beyond? Science. 2013;341(6147):759-765. doi:10.1126/science.1237591.

[275] Palikhe BR. Relationship between pesticide use and climate change for crops. Journal of Agriculture and Environment. 2007;8:83-91. doi:10.3126/aej.v8i0.731.

[276] Weale A. Ethical arguments relevant to the use of GM crops. New Biotechnology. 2010;27(5):582-587. doi:10.1016/j.nbt.2010.08.013.

[277] Garcia P, Bezerra G, Feldmann F. Brazil - The Environment and Climate Change Law Review; 2018. Available from: https://thelawreviews.co.uk/edition/the-environment-andclimate-change-law-review-edition-2/1153044/brazil.

[278] See IBAMA's Normative Instruction No. 05/2012 and Federal Decree No. 6,514/2008.

[279] Mano A. Brazil pesticide group to appeal ruling suspending glyphosate weed killer. Reuters. 2018 Aug 8;Https://www.reuters.com/article/us-brazilagriculture-chemicals/brazil-pesticide-group-to-appeal-

ruling-suspending-glyphosate-weed-killer-idUSKBN1KT2E4.

https://www.reuters.com/article/us-brazil-agriculture-

chemicals/brazil-pesticide-group-to-appeal-ruling-suspendingglyphosate-weed-killer-idUSKBN1KT2E4.

[280] Langlois J. Brazilian lawmakers seek to deregulate pesticide use and ban sale of organic produce in major supermarkets. Los Angeles Times. 2018; Available from: https://www.latimes.com/world/lafg-brazil-farming-pesticides-20180812-htmlstory.html.

[281] Wagner F, Ward JO. Urbanization and migration in Brazil. American Journal of Economics and Sociology. 1980;39(3):249-259. doi:10.1111/j.1536-7150.1980.tb01276.x.

[282] Lapola DM, Martinelli LA, Peres CA, Ometto JP, Ferreira ME, Nobre $\mathrm{CA}$, et al. Pervasive transition of the Brazilian land-use system. Nature climate change. 2014;4(1):27. doi:10.1038/nclimate2056.

[283] Branford S, Torres M. Temer seeks to privatize Brazil's deforestation remote sensing program. Mongabay. 2017 May 26; Available from: https://news.mongabay.com/2017/05/temer-seeks-toprivatize-brazils-deforestation-remote-sensing-program/.

[284] Lima M, Skutsch M, de Medeiros Costa G. Deforestation and the social impacts of soy for biodiesel: perspectives of farmers in the South Brazilian Amazon. Ecology and Society. 2011;16(4). Available from: http://www.jstor.org/stable/26268958.

[285] Cassel A, Patel R. Agricultural trade liberalization and Brazil's rural poor: Consolidating inequality. Food First Policy Brief. 2003;8. Available from: https://foodfirst.org/wpcontent/uploads/2013/12/PB8-Brazils-Rural-Poor-ConsolidatingInequality_Cassel-and-Patel_Aug2003.pdf.

[286] Chaddad F, Valentinov V. Agency costs and organizational architecture of large corporate farms: evidence from Brazil. International Food and Agribusiness Management Review. 2017;20(2):201-220. doi:10.22434/IFAMR2016.0009.

[287] Thoumi G. Farmland Investments In Brazilian Cerrado: Financial, Environmental, And Social Risks. Seeking Alpha. 2017 Oct 18;
Available from: https://seekingalpha.com/article/4114248-farmlandinvestments-brazilian-cerrado-financial-environmental-socialrisks.

[288] Conant J. Is Land Speculation Helping Destroy Brazil's "Birthplace of Waters"? Grassroots International. 2018; Available from: https://grassrootsonline.org/in-the-news/is-land-speculationhelping-destroy-brazils-birthplace-of-waters/.

[289] MST members occupy land that fails to fulfill its social function as defined by the Brazilian Constitution. Article 186 of the Brazilian Constitution states that social function is performed when rural property simultaneously meets the requirements of: a. rational and adequate use; $b$. adequate use of available natural resources and preservation of the environment; c. compliance with provisions that regulate labor relations; and $d$. land use that favors the well-being of the owners and workers.

[290] A loophole in the Brazilian Constitution allows for the government to expropriate unused land and grant it to landless farmers, so the MST uses this law to take over unused land and fight for legal recognition to own it.

[291] Zobel G. We Are Millions. New Internationalist; 2009. Available from: https://newint.org/features/special/2009/12/01/we-are-millions.

[292] Carter M. The landless rural workers movement and democracy in Brazil. Latin American Research Review. 2010;45:186-217. Available from: https://www.jstor.org/stable/27919219.

[293] Mello J. Contemporary Slavery in Brazil. The Brazil Business. 2012; Available from: https://thebrazilbusiness.com/article/theagribusiness-in-chains.

[294] Sharma B. Contemporary forms of slavery in Brazil. London, UK; 2006.

[295] Eating up the Amazon. Greenpeace; 2006. Available from: https://www.greenpeace.org/austria/Global/austria/ marktcheck/uploads/media/eating-up-the-amazon_report.pdf.

[296] For example, organizations such as the US Coalition of Immokalee Workers.

[297] Freudenberger M. Land Tenure and Global Climate Change: Best Practices for Land Tenure and Natural Resource Governance in Africa; 2012. Available from: https://www.land-links.org/wp-content/uploads/2016/09/Module-4Climate-Change-and-Tenure-Freudenberger.pdf.

[298] Doorey DJ. A Law of Just Transitions?: Putting Labor Law to Work on Climate Change. SSRN Electronic Journal. 2015; doi:10.2139/ssrn.2680241.

[299] Nicholson H. 8 ways fairtrade farmers protect the environment. Fairtrade Foundation; 2018. Available from: http://www.fairtrade.org.uk/Media-Centre/Blog/2018/June/8ways-Fairtrade-protects-the-environment.

[300] Environment and Natural Resouces Series No. 4. Rome, Italy: United Nations FAO. Available from: http://www.fao.org/docrep/005/ y4137e/y4137e02b.htm.

[301] Food, of the United Nations (FAO) AO. The Future of Food and Agriculture. Trends and Challenges. Rome, Italy: FAO; 2017. Available from: http://www.fao.org/3/a-i6583e.pdf.

[302] Spring J. Appetite for destruction: Soy boom devours Brazil's tropical savanna. Reuters. 2018; Available from: https://www.reuters. com/investigates/special-report/brazil-deforestation/.

[303] Mol AP, Oosterveer P. Certification of markets, markets of certificates: Tracing sustainability in global agro-food value chains. Sustainability. 2015;7(9):12258-12278. doi:10.3390/su70912258.

[304] Roundtable on Responsible Soya-the Certifying Smoke Screen GM, Freeze and Friends of the Earth and CEO. 2012; Available from: https://corporateeurope.org/sites/default/files/publications/ rtrs_briefing2012_0.pdf.

[305] RPT-Ethical investment tide lifts "greenwash" concerns. Reuters. 2017; Available from: https://www.reuters.com/article/investmentethics/rpt-ethical-investment-tide-lifts-greenwash-concernsidUSL3N1H83JI.

[306] Stewart G. Sustainable finance: Can socially responsible investing mitigate climate change? Open Democracy. 2017; Available from: https://www.opendemocracy.net/en/opendemocracyuk/ sustainable-finance-can-socially-responsible-investing-mitigateclimate-change/.

[307] Quigley A. Norway adopts world's first zero deforestation policy: 
What does that mean? Christian Science Monitor. 2016; Available from: https://www.csmonitor.com/Environment/2016/0608/Norwayadopts-world-s-first-zero-deforestation-policy-What-does-thatmean.

[308] Nature for life, Norway's national biodiversity action plan, White paper. Norwegian Ministry of Climate and Environment; 2015-2016. Available from: https://www.regjeringen. no/contentassets/902deab2906342dd823906d06ed05db2/en$\mathrm{gb} / \mathrm{pdfs} / \mathrm{stm} 201520160014000$ engpdfs.pdf.

[309] Pohlman K. Norway Becomes World's First Country to Ban Deforestation. EcoWatch. 2016; Available from: https://www.ecowatch. com/norway-becomes-worlds-first-country-to-ban-deforestation1891166989. html?xrs=RebelMouse_fb\&ts $=1537697558$.

[310] Butler R. Norway pays Brazil $\$ 1 B$ to fulfill pledge for curbing deforestation. Mongabay. 2015; Available from: https://news.mongabay.com/2015/09/norway-pays-brazil-1bto-fulfill-pledge-for-curbing-deforestation/.

[311] Howard B. Brazil leads world in reducing carbon emissions by slashing deforestation. National Geographic. 2014; Available from: https://news.nationalgeographic.com/news/2014/06/140605brazil-deforestation-carbon-emissions-environment/.

[312] Lang C. While Brazil's deforestation soars, the Environment Ministry announces cuts in emissions from deforestation. REDD Monitor. 2018; Available from: https://redd-monitor.org/2018/08/11/whilebrazils-deforestation-soars-the-environment-ministry-announcescuts-in-emissions-from-deforestation/.

[313] Tollefson J. Political appointments spur concerns for Amazon: environmentalists worried after Brazilian president picks ministers with ties to agriculture lobby. Nature. 2015;517(7534):251-253. Available from: http://www.nature.com/doifinder/10.1038/517251a.

[314] Fearnside PM. Environment: deforestation soars in the Amazon. Nature. 2015;521(7553):423. doi:10.1038/521423b.

[315] Spanne A. Hunger for Meat Plows Up Brazil's Cerrado Plains. The Daily Climate; 2014. Available from: https://www.scientificamerican. com/article/hunger-for-meat-plows-up-brazils-cerrado-plains/.

[316] Signatories to the Cerrado Manifesto Statement of Support. Farm Animal Investment Risk \& Return. 2018; Available from: https: //cerradostatement.fairr.org.

[317] Jepson P, Collaco de Carvalho S. Brazil's Cerrado forests won't be saved by corporate pledges on deforestation. The Conversation. 2017; Available from: http://theconversation.com/brazils-cerradoforests-wont-be-saved-by-corporate-pledges-on-deforestation87130.

[318] da Silva VdPR, de Oliveira SD, Hoekstra AY, Dantas Neto J, Campos JHB, Braga CC, et al. Water footprint and virtual water trade of Brazil. Water. 2016;8(11):517. doi:10.3390/w8110517.

[319] Murphy S. Free trade in agriculture: A bad idea whose time is done. Monthly Review. 2009;61(3):78. doi:10.14452/MR-061-03-2009076.

[320] Browder JO. Redemptive communities: Indigenous knowledge, colonist farming systems, and conservation of tropical forests. Agriculture and Human Values. 1995;12(1):17-30. doi:10.1007/BF02218071.

[321] Ajayi O, Mafongoya P. Indigenous knowledge systems and climate change management in Africa. CTA; 2017. Available from: https://cgspace.cgiar.org/handle/10568/91189?show=full.

[322] Raygorodetsky G. Why traditional knowledge holds the key to climate change. United Nations University: Climate Change, Culture and Religions. 2011 Dec 13; Available from: https://unu.edu/publications/articles/why-traditionalknowledge-holds-the-key-to-climate-change.html.

[323] Schwartzman S, Boas AV, Ono KY, Fonseca MG, Doblas J, Zimmerman $\mathrm{B}$, et al. The natural and social history of the indigenous lands and protected areas corridor of the Xingu River basin. Philosophical Transactions of the Royal Society B: Biological Sciences. 2013;368(1619):20120164. doi:10.1098/rstb.2012.0164

[324] Welch JR, Brondízio ES, Hetrick SS, Coimbra Jr CE. Indigenous burning as conservation practice: Neotropical savanna recovery amid agribusiness deforestation in Central Brazil. PLoS One. 2013;8(12):e81226. doi:10.1371/journal.pone.0081226.

[325] Organizations representing tribal interests include APOINME, MOPIC, and Campanha Y Ikatu Xingu.
[326] Summers J, Smith L. The role of social and intergenerational eq uity in making changes in human well-being sustainable. Ambio. 2014:43(6):718-728. doi:10.1007/s13280-013-0483-6.

[327] Convention concerning the protection of the world cultural and natural heritage: adopted by the General conference at its seventeenth session, Paris, 16 November 1972. Unesco; 1972. Available from: http://whc.unesco.org/archive/convention-en.pdf.

[328] Recommendations of the Vth IUCN World Parks Congress. International Union for Conservation of Nature; 2003. Available from: http://www.uicnmed.org/web2007/CDMURCIA/pdf/durban/ recommendations_en.pdf.

[329] See also ECOLEX, an information service on environmental law, operated jointly by FAO, IUCN and UNEP. https://www.ecolex.org.

[330] Maljean-Dubois S, Wemaere M. Climate Change and Biodiversity. Available from: https://halshs.archives-ouvertes.fr/halshs01675503.

[331] Witness G, Kuepper G, Lacerda M, Gardiner S, HartzellNichols L, Andrade F, et al. Cerrado: Sarney Filho propõe moratória da soja. Canal Rural / UOL. 2018; Available from: https://www.destakjornal.com.br/brasil/eleicoes2018/detalhe/veja-as-frases-mais-polemicas-dos-candidatosneste-2-turno?ref=Brasil_Ultimas.

[332] Gardiner SM. A perfect moral storm: the ethical tragedy of climate change. Oxford University Press; 2011.

[333] Markell DL, Ruhl JB. An Empirical Assessment of Climate Change in the Courts: A New Jurisprudence or Business as Usual? SSRN Electronic Journal. 2011; doi:10.2139/ssrn.1762886.

[334] These pledges included reducing GHGs by between $36.1 \%$ and $38.9 \%$; an $80 \%$ reduction in the rate of deforestation in the Amazon and $40 \%$ in the Cerrado; the intensive recovery of degraded agricultural lands; the active promotion of crop, forestry, and livestock integration; the expansion of a tillage system that utilizes Biological Nitrogen Fixation; the expansion of the use of technologies to treat animal waste; and the intensification of reforestation efforts..

[335] Rouseff D. Brazil: Statement by HE Dilma Rouseff, President of the Federative Republic of Brazil, at the Summit for the Adoption of the 2030 Agenda for Sustainable Development; 2015.

[336] Asher C. Brazil's actual forest-related $\mathrm{CO} 2$ emissions could blow by Paris pledge. Mongabay. 2018 Apr 19; Available from: https://news.mongabay.com/2018/04/brazils-actual-forestrelated-co2-emissions-could-blow-by-paris-pledge/.

[337] van Asselt $\mathrm{H}$. International climate change law in a bottom-up world 2016; Available from: http://www.qil-qdi.org/wp-content/uploads/ 2016/03/02_COP21_ASSELT_FIN-2.pdf.

[338] GHG Protocol Agricultural Guidance: Interpreting the Corporate Accounting and Reporting Standard for the agricultural sector GHG Protocol Agricultural Guidance. Greenhouse Gas Protocol, World Resources Institute; 2014. Available from: https: //ghgprotocol.org/sites/default/files/standards/GHG\%20Protocol\% 20Agricultural\%20Guidance\%20\%28April\%2026\%29_0.pdf.

[339] Wedy G. Climate Change and Sustainable Development in Brazilian Law. SSRN Electronic Journal. 2016 March 1; Available from: http://ssrn.com/abstract=2746195.

[340] Brazil Case Study Analysis of National Strategies for Sustainable Development; 2004. Available from: https://www.iisd.org/pdf/2004/ measure_sdsip_brazil.pdf.

[341] Legislação citada anexada pela Coordenação de Estudos Legislativos-CEDI. Available from: http://www.camara.gov. $\mathrm{br} /$ proposicoesWeb/prop_mostrarintegra?codteor $=841507 \&$ filename=LegislacaoCitada+-.

[342] Wedy G. Climate Legislation and Litigation in Brazil; 2017. Available from: http://columbiaclimatelaw.com/files/2017/10/Wedy-2017-10Climate-Legislation-and-Litigation-in-Brazil.pdf.

[343] Darby M. Brazil: Bolsonaro threatens to quit Paris climate deal. Climate Home News. 2018; Available from: http://www.climatechangenews.com/2018/08/14/brazilsbolsonaro-threatens-quit-paris-climate-deal/.

[344] Rochedo PR, Soares-Filho B, Schaeffer R, Viola E, Szklo A, Lucena $A F$, et al. The threat of political bargaining to climate mitigation in Brazil. Nature Climate Change. 2018;8(8):695. doi:10.1038/s41558018-0213-y.

[345] Carrascosa von Glehn H, Taffarello D, Pagiola S. Brazil's experience 
with payments for environmental services. 2013; Available from: http://documents.worldbank.org/curated/en/554361468020374079/ pdf/862700NWP0ENGL00Box385172B00PUBLIC0.pdf.

[346] Azevedo AA, Rajão R, Costa MA, Stabile MC, Macedo MN, dos Reis TN, et al. Limits of Brazil's Forest Code as a means to end illegal deforestation. Proceedings of the National Academy of Sciences. 2017;114(29):7653-7658. doi:10.1073/pnas.1604768114.

[347] da República Brasil P. Law 12.805. Available from: http://www.Ise. ac.uk/Granthamlnstitute/wp-content/uploads/laws/1091.pdf.

[348] Sawyer D, Mesquita B, Coutinho B, de Almeida F, Figueiredo I, Lamas I, et al.. Ecosystem Profile: Cerrado Biodiversity Hotspot. Critical Ecosystem Partnership Fund; 2016. Available from: https://www.cepf.net/sites/default/files/cerrado-ecosystemprofile-en-updated.pdf.

[349] Angelo C. Brazil's fund for low-carbon agriculture lies fallow. Nature. 2012;10. Available from: http://www.nature.com/doifinder/10.1038/ nature.2012.11111.

[350] Meijboom FL, Stafleu FR. Farming ethics in practice: from freedom to professional moral autonomy for farmers. Agriculture and Human Values. 2016;33(2):403-414. doi:10.1007/s10460-015-9641-8.

[351] Brazil Corruption Report. GAN. 2017; Available from: https: //www.business-anti-corruption.com/country-profiles/brazil/.
[352] Deadly Environment: The Dramatic Rise in Killings of Environmental and Land Defenders, 1.1. 2002++31.12. 2013. Witness, Global. 2014; Available from: https://globalinitiative.net/wp-content/uploads/ 2017/12/Global-Witness-Deadly-Environment-June-2014.pdf.

[353] Defenders of the Earth Report. Witness, Global. 2017; Available from: https:/www.globalwitness.org/en-gb/campaigns/ environmental-activists/defenders-earth/.

[354] On Dangerous Ground: 2015's Deadly Environment: the Killing and Criminalization of Land and Environmental Defenders Worldwide. Witness, Global. 2016; Available from: https://www.globalwitness. org/en/campaigns/environmental-activists/dangerous-ground/.

[355] Strassburg BB, Latawiec AE, Barioni LG, Nobre CA, Da Silva VP, Valentim JF, et al. When enough should be enough: Improving the use of current agricultural lands could meet production demands and spare natural habitats in Brazil. Global Environmental Change. 2014;28:84-97. doi:10.1016/j.gloenvcha.2014.06.001.

[356] Macedo MN, DeFries RS, Morton DC, Stickler CM, Galford GL, Shimabukuro YE. Decoupling of deforestation and soy production in the southern Amazon during the late 2000s. Proceedings of the National Academy of Sciences. 2012;109(4):1341-1346. doi:10.1073/pnas.1111374109. 